\title{
The Spectrum of Anti-Chromatin/Nucleosome Autoantibodies: Independent and Interdependent Biomarkers of Disease
}

\author{
Sonal Mehra ${ }^{1}$ and Marvin J. Fritzler ${ }^{2}$ \\ ${ }^{1}$ Department of Clinical Immunology, JIPMER, 605006 Puducherry, India \\ ${ }^{2}$ Faculty of Medicine, University of Calgary, 3330 Hospital Drive NW, Calgary, AlB, Canada T2N 4N1
}

Correspondence should be addressed to Marvin J. Fritzler; fritzler@ucalgary.ca

Received 13 January 2014; Accepted 3 March 2014; Published 3 April 2014

Academic Editor: Michael Mahler

Copyright (c) 2014 S. Mehra and M. J. Fritzler. This is an open access article distributed under the Creative Commons Attribution License, which permits unrestricted use, distribution, and reproduction in any medium, provided the original work is properly cited.

\begin{abstract}
Autoantibodies directed to chromatin components date back to the discovery of the LE cell and the LE cell phenomenon circa 1950, and subsequent evidence that major components of that reaction were chromatin components and histones in particular. Over time, immunoassays ranging from ELISA and line immunoassays to more modern bead-based assays incorporated histone and DNA mixtures, purified histones, and purified nucleosomes leading to a more thorough understanding of the genesis and pathogenetic relationships of antibodies to chromatin components in systemic lupus erythematosus and other autoimmune conditions. More recently, interest has focussed on other components of chromatin such as high mobility group (HMG) proteins both as targets of B cell responses and pro-inflammatory mediators. This review will focus on immunoassays that utilize chromatin components, their clinical relationships, and newer evidence implicating HMG proteins and DNA neutrophil extracellular traps (NETs) as important players in systemic autoimmune rheumatic diseases.
\end{abstract}

\section{Introduction}

Eukaryotic chromatin is comprised of approximately $40 \%$ DNA, 40\% histones, $20 \%$ nonhistone proteins (i.e., HMG proteins), RNA, and other macromolecules. The fundamental subunit of chromatin is the mononucleosome, which is composed of 180 base pairs of DNA and two molecules each of the core histones $\mathrm{H} 2 \mathrm{~A}, \mathrm{H} 2 \mathrm{~B}, \mathrm{H} 3$, and $\mathrm{H} 4$ and one of the linker histone $\mathrm{H} 1$. The core histones are organized as a histone octamer (containing two $\mathrm{H} 2 \mathrm{~A}-\mathrm{H} 2 \mathrm{~B}$ dimers and one $\mathrm{H} 3-\mathrm{H} 4$ tetramer) around which 146 base pairs of DNA are wrapped, thus constituting the "core particle." This structure is stabilized by histone H1 which binds across the surface of the nucleosome [1]. The periodic arrangement of nucleosomes along DNA strands gives chromatin a "beads on a string" appearance in electron micrographs [2]. The "beads" representing mononucleosomes can be isolated by digesting the internucleosomal linker DNA with micrococcal nuclease (reviewed in $[3,4]$ ).

Human autoantibodies that bind to chromatin targets can be divided into those that recognize dsDNA, protein components of chromatin (i.e., histones, HMG proteins), mononucleosomes, or macromolecular components of nucleosomes as represented by low salt extracted nucleosomes (core particle) [3,5-7]. Schematically, the family of antinucleosome autoantibodies ( $\mathrm{ANuA}$ ) are primarily directed against histone epitopes localized primarily to exposed domains of native chromatin (i.e., carboxyl terminal tails of core histones), double-stranded DNA (dsDNA), and conformational epitopes created by the interaction between dsDNA and core histones (reviewed in $[3,8]$ ). This review discusses recent studies that explored the pathogenicity, diagnostic relevance, and clinical impact of anti-dsDNA and ANuA with a primary focus on SLE and an overview of more recent advances that are impacting on this field of study and clinical applications.

\section{Anti-dsDNA Antibodies}

Anti-dsDNA are quite specific for SLE, although they have been found in normal individuals where they are mostly 
the IgM isotype as encoded by germline DNA with few or no somatic mutations $[9,10]$. These IgM belong to a family of natural autoantibodies, tend to have low affinity and avidity binding characteristics, and display polyreactivity [11]. For the most part, they are not pathogenic [12], demonstrate geographical differences in frequency [13], and may be protective by virtue of possessing enzymatic activity (abzymes) that can degrade nucleic acids [11]. By comparison, pathogenic anti-dsDNA antibodies are thought to be high-avidity IgG isotypes that react with dsDNA and are somatically mutated as expression of an antigen driven selection process [14, 15]. The natural anti-dsDNA antibodies are produced by a B1 $(\mathrm{CD} 5+) \mathrm{B}$ cell subpopulation, while the pathogenic subsets are secreted by B2 (CD5-) B lymphocytes [16]. The naive B cells specific for ssDNA may clonally expand if stimulated by immunogenic DNA and gain specificity for dsDNA as a consequence of somatic mutations under antigenic stimulation pressure [15].

Autoantibodies to dsDNA were first recognized as an important serological marker for the diagnosis of idiopathic SLE, and eventually both the American College of Rheumatology and Systemic Lupus International Cooperating Clinics (SLICC) criteria for classification of the disease included the presence of these autoantibodies as a formal criterion $[17,18]$. Antibodies directed against dsDNA and nucleosomal chromatin have been reported as sensitive biomarkers for the diagnosis of SLE and quantitatively associated with disease activity $[8,19]$. Historically, anti-dsDNA autoantibodies in particular were associated with renal involvement [20-23] and they have also been found in immune complex deposits in the glomeruli of SLE patients [24]. Depending on the diagnostic platform used for their detection, anti-dsDNA antibodies are found in approximately 50\% of SLE patients $[3,24]$. Besides anti-dsDNA, nucleosome-specific antibodies and nucleosome-antinucleosome immune complexes have also been shown to play a major role in the pathophysiology of SLE $[23,25]$.

\section{Anti-Nucleosome Antibodies (ANuA)}

By comparison, ANuA are a more sensitive biomarker of SLE than anti-dsDNA and are almost exclusively found in SLE and in much lower frequency in systemic sclerosis (SSc), mixed connective tissue disease, and other systemic autoimmune rheumatic diseases (SARD) [26]. Several published studies evaluated ANuA in SLE with various findings [27-30]. The point prevalence of ANuA in SLE varies from 50\% to $90 \%$ $[31,32]$ and their presence can be used, in conjunction with clinical findings and other laboratory tests, to support the diagnosis of SLE and certain cases of drug induced lupus (DIL) [3]. Recently, newer immunoassay platforms, including multiplexed microarrays used for detecting ANuA and antidsDNA, have been found to be promising in assessing disease activity, especially when anti-dsDNA antibodies are negative [27].

\section{Nucleosomes Drive Anti-Chromatin Autoantibody Production}

SLE is characterized by the production of both antigen driven autoantibodies such as anti-dsDNA and anti-histone antibodies and polyclonal, apparently nonspecific, autoantibodies. Precise mechanisms leading to production of these autoantibodies are still unclear, but several data suggest that the nucleosome plays a key role [23-25]. Since purified DNA has been known to be a poor immunogen $[33,34]$ and the immune response is most commonly directed to riboand deoxyribonucleoproteins (i.e., small nuclear and small cytoplasmic RNPs such as Sm, U1RNP, SS-A/Ro60), it seems more plausible that the nucleosome is the primary antigen that drives the anti-dsDNA [9] and anti-histone responses via inter- and intramolecular epitope spreading.

An understanding of the sources of the nucleosomes that drive the anti-chromatin response is becoming more and more complex. It has been held for almost two decades that aberrant apoptosis and a reduced clearance of apoptotic cells by phagocytes may lead to an increased exposure of apoptotic nucleosomes to the immune system (reviewed in $[31,35,36]$ ). It should be added that although a lot of attention has focussed on apoptosis as a key paradigm in autoantigen release and the resulting $\mathrm{B}$ and $\mathrm{T}$ cell responses, other mechanisms of autoantigen release from necrotic or damaged cells [37-39], circulating microparticles [40,41], or DNA neutrophil extracellular traps (NETs) [39], discussed later in this review, need also to be taken into consideration.

Nevertheless, a prevailing paradigm is that nucleosomal constituents, which have been cleaved and modified (i.e., acetylated, methylated) during the process of apoptosis [42, 43], escape normal clearance and express epitopes that are not normally encountered by the immune system [36]. This may lead to breaking of tolerance via polynucleosomes produced during cell apoptosis and their subsequent binding to activated monocytes which may present these antigens cells to CD4+ T-helper cells, inducing an antigen-driven response [44]. In murine lupus, ANuA antedate many other autoantibodies $[45,46]$ and nucleosome-specific CD4+ T cells are detected earlier than the pathogenic autoantibodies, suggesting that cellular immunity may play a key role in triggering and the onset of disease [45, 47]. Lartigue et al. [48] studied the $l p r$ mutation in murine lupus and found that the Toll-like receptor 9 (TLR9) is absolutely required for the ANuA response but not for anti-dsDNA antibody production. As a general paradigm, apoptosis results in modified chromatin components appearing at the surface of apoptotic cells, the removal of apoptotic debris is defective, and the massive release of these nucleosomes into the circulation incites their recognition by the immune system ( $T$ and B cells) and the production of ANuA [49].

A number of reports have discussed the role of circulating microparticles generated in vitro that also displayed DNA and other nucleosomal structures in an antigenic form [40, 41]. These microparticles may be related to blebs that form during cell death and contain both cytoplasmic and nuclear components such as DNA and RNA [50]. It was suggested that the blood of SLE patients can contain microparticles with 
bound $\operatorname{IgG}$ favouring a type of immune complex that may contribute to pathogenesis of SLE [40].

The notion that one of the primary B cell targets in SLE is the nucleosome is supported by a number of observations. Autoantibodies directed against histones are found in 95$100 \%$ of DIL sera and also in $70 \%$ of SLE $[3,51]$. Early studies suggested that subunits of the nucleosome rather than free histones are highly antigenic in procainamideinduced lupus [52, 53]. Subsequent studies demonstrated that antibodies directed against the (H2A-H2B)-DNA subnucleosome particle were a serological feature of DIL $[4,54]$. These studies implicated the nucleosome rather than its component proteins or DNA as the immunogenic stimulus for antibody appearance in drug-induced autoimmunity (DIA) or in DIL in the absence of symptoms (reviewed in $[3,4]$ ). This was supported by observations that ANuA can be detected very early during the disease (i.e., before intramolecular epitope spreading to anti-dsDNA and antihistone responses) and is potentially nephritogenic in lupus mice $[55,56]$. Thus, breaking peripheral tolerance leading to $\mathrm{ANuA}$, immune complex formation and activation of complement could be related to nucleosomes rendered immunogenic by being present in large excess and/or harboring modifications. It has been shown that a large part of ANuA activity is attributable to nucleosome-restricted autoantibodies and is distinct from anti-dsDNA and anti-histone reactivity $[56,57]$. In addition, it has been demonstrated that antigens other than DNA can initiate the anti-dsDNA antibody responses $[58,59]$. Furthermore, there is evidence that IgG anti-dsDNA autoantibodies can shuttle nucleic acid fragments through the plasma membrane causing activation and secretion of inflammatory cytokines contributing to the pathogenesis in SLE (reviewed in [60]). The debate about autoantibodies penetrating living cells has persisted for almost four decades [61] and despite resistance to the idea [62], it is a concept that refuses to go away (reviewed in [63]).

\section{Diagnostic Assays for the Detection of Anti-dsDNA and ANuA}

Over the last five decades since their first description, several methods for anti-dsDNA detection have been developed (reviewed in $[64,65]$ ). The most commonly used immunoassays are the Crithidia luciliae immunofluorescence test (CLIFT) and various enzyme-linked immunoassays (ELISA). More recently, other methods include the use of strips blotted with the DNA molecules (immunoblotting (IB) and line immunoassays (LIA)) and the use of microarrays and addressable laser bead immunoassays (ALBIA) [6668]. There is evidence that the various immunoassays differ in sensitivity and/or specificity and may identify different autoantibodies with different diagnostic and prognostic values. Although the Farr radioimmunoassay was widely acclaimed as the assay of choice because the results can be correlated with global SLE activity and renal and vasculitis involvement, it has been largely replaced by nonradioisotopic techniques, mainly indirect immunofluorescence tests using purified circular dsDNA as would be represented in the Crithidia luciliae kinetoplast and purified dsDNA in an ELISA [64, 65].

In a multicenter study of four different anti-dsDNA immunoassays, autoantibody titres detected by EliA and FARR assay were correlated with SLE disease activity [69]. It has been shown that low-avidity autoantibodies are primarily detected by ELISAs (as well as complement fixation, hemagglutination, and polyethylene glycol (PEG) assays), mediumto-low-avidity autoantibodies by CLIFT, while high-avidity antibodies are most reliably detected by the Farr assay [15]. ALBIA has also been developed to detect anti-dsDNA but this assay platform has been troubled with lack of precision and a challenge in correlating the results with other established platform assays [70-72].

A more recently developed high avidity anti-dsDNA IgG ELISA is reported to have highly specific performance characteristics for the SLE although it is less sensitive than certain other dsDNA IgG assays [73]. In a multicentre study of SLE patients, anti-dsDNA antibodies were detected in serum by means of a "Farrzyme" assay, fluoroenzyme immunoassay (EliA), CLIFT, or Farr [74]. The sensitivity for SLE ranged from 66\% with Farrzyme to $95 \%$ with Farr, with about $90 \%$ specificity for all the methods tested. The four methods correlated with disease activity and renal or haematologic involvement and showed a negative association with central nervous system disease [74]. Another study suggested that these EIA tests may replace CLIFT as a screening test and the Farr assay as a specific test for antidsDNA antibody detection [75]. Therefore, screening with the sensitive ELISA detects most anti-dsDNA antibodies irrespective of pathogenic impact [76], and follow-up positive ELISA results by more stringent assays (CLIFT, FARR assay with circular dsDNA as antigen, EliA anti-dsDNA assays, or solution-phase ELISA) will determine the presence of potentially more pathogenic anti-dsDNA antibodies [77, 78].

ELISA techniques for ANuA detection differ in terms of the antigen preparations used. Some methods use purified nucleosomal particles obtained by reconstituting histone core proteins or histone dimers onto DNA; others use purified chromatin generally obtained by digestion with micrococcal nuclease and subsequent removal of histone $\mathrm{H} 1$ and HMG proteins with $0.5 \mathrm{M} \mathrm{NaCl}$ at a neutral $\mathrm{pH}$ [79]. Because it was demonstrated that the presence of the $\mathrm{H} 1$ histone in the preparation of nucleosomes was a cause of "false positive reactions," many manufacturers modified the antigenic preparations by stripping the $\mathrm{H} 1$ histone and, in the course of that treatment, also most HMG proteins from the nucleosomal complex [35]. Hence, assays that employ reconstituted nucleosomes or nucleosomes stripped of $\mathrm{H} 1$ do not measure HMG antibodies as well. Studies of SLE sera using assays that employed H1-stripped nucleosomes and those that used whole nucleosomes were shown to have comparable sensitivity ( $61 \%$ versus $59 \%$ ), but the specificity of H1-stripped nucleosome was much better than that for assays that used whole nucleosomes (95.7\% versus $87.5 \%$ ) (reviewed in [8]).

Bardin et al. [80] found that a multiplexed addressable laser bead immunoassay (BioPlex 2200: BioRad) used for the simultaneous detection of both ANuA and anti-dsDNA 
TABLE 1: ANuA in SLE compared to controls*.

\begin{tabular}{|c|c|c|c|}
\hline Authors [reference] & $\begin{array}{c}\text { ANuA in SLE cohort } \\
\text { sensitivity/specificity } \\
(n)\end{array}$ & $\begin{array}{c}\% \\
\text { anti-dsDNA } \\
\text { in SLE cohort }\end{array}$ & ANuA clinical and serological associations \\
\hline Sardeto et al., 2012 [88] & $62 / 100(92)$ & 40 & Disease activity, anti-dsDNA \\
\hline Suleiman et al., 2009 [89] & $52 / 98(90)$ & 37 & Disease activity, anti-DNA \\
\hline Kim et al., 2008 [95] & 98/78 (100) & $\mathrm{nr}$ & $\begin{array}{l}\text { Leucopenia, low complement, disease activity, } \\
\text { anti-dsDNA }\end{array}$ \\
\hline Bossuyt et al., 2008 [103] & $78 / 73(40)$ & 65 & $\begin{array}{l}\text { Proteinuria, disease flare, ANuA but not anti-dsDNA } \\
\text { found in TNF alpha inhibitor related ANA }\end{array}$ \\
\hline Grootscholten et al., 2007 [83] & $81 / \mathrm{nr}(52)(\mathrm{LSLN})$ & 96 & $\begin{array}{l}\text { Disease activity but not disease course, } \mathrm{LN} \text {, } \\
\text { anti-histone, anti-Clq }\end{array}$ \\
\hline Su et al., 2007 [96] & $62 / 98(233)$ & $\mathrm{nr}$ & Disease activity, malar rash, arthralgia, anti-dsDNA \\
\hline Düzgün et al., 2007 [6] & $55 / 98(131)$ & $\mathrm{nr}$ & Disease activity, LN, anti-dsDNA \\
\hline Tikly et al., 2007 [97] & $45 / 94(86)$ & $\mathrm{nr}$ & $\begin{array}{l}\text { Disease activity, discoid lupus/malar rash, anti-dsDNA, } \\
\text { aCL }\end{array}$ \\
\hline Braun et al., 2007 [94] & 64/99 (78) & & Disease activity, anti-dsDNA, anti-Clq \\
\hline Campos et al., 2006 [110] & 53/98 (74) (JSLE) & 54 & $\begin{array}{l}\text { Disease activity, malar rash, hemolytic anemia, low } \\
\text { complement, anti-dsDNA }\end{array}$ \\
\hline Simón et al., 2004 [85] & 100/97 (73) & 63 & $\begin{array}{l}\mathrm{LN} \text {, malar rash, arthritis, oral ulcers, pleuritis, disease } \\
\text { activity, renal damage }\end{array}$ \\
\hline Ghirardello et al., 2004 [93] & $86 / 95(101)$ & 69 & Hematological, anti-dsDNA \\
\hline Cairns et al., 2003 [28] & $64 / 99(95)$ & $\mathrm{nr}$ & LN, hematological, anti-dsDNA \\
\hline Cervera et al., 2003 [29] & 69/92 (100) & $\mathrm{nr}$ & LN, anti-dsDNA \\
\hline Min et al., 2002 [26] & 76/98 (129) & 79 & Disease activity, low complement, anti-dsDNA \\
\hline Amoura et al., 2000 [27] & $72 / 90(120)$ & $\mathrm{nr}$ & Disease activity, LN \\
\hline
\end{tabular}

aCL: anticardiolipin; CLE: cutaneous lupus erythematosus, ANuA: anti-nucleosome antibodies; dsDNA: double-stranded DNA; JSLE: juvenile systemic lupus erythematosus; LN: lupus nephritis; nr: not reported; NRL: nonrenal lupus; LSLN: longitudinal study of lupus nephritis; nr: not reported.

${ }^{*}$ Some data adapted from $[4,8]$.

autoantibodies increased the sensitivity for SLE from 68$70 \%$ when only one antibody was detected (anti-dsDNA or $\mathrm{ANuA}$ ) to $78 \%$ when both antibodies were detected. This was suggested to be especially useful in followup of SLE patients with active lupus nephritis. Similarly, in a retrospective study of 764 patients with rheumatic diseases, Bose et al. used the multiplexed Bioplex 2200 ANA screen to simultaneous determine of autoantibodies to extractable nuclear antigens and ANuA [81]. The sensitivity, specificity, positive predictive value, and negative predictive value of the ANuAs in SLE were 62.4\%, 91.5\%, 50.4\%, and 94.6\%, respectively. Of note, no correlation was found between the $\mathrm{ANuA}$ and lupus glomerulonephritis or anti-dsDNA antibodies. In our experience it is very difficult to multiplex assays where ligands or components of macromolecular complexes (i.e., nucleosomes, DNA, histones) are included in the same assay. Therefore, although newer advancements like microarrays and multiplexed immunoassays have great potential for research and diagnostic applications in SLE and other SARD [66], a number of technical hurdles need to be overcome.

\section{Clinical Associations of Anti-dsDNA and ANuA in SLE}

At the outset, it must be made clear that $\mathrm{ANuA}$ represents a very complex autoantibody system comprising a variety of potential protein targets, epitopes, and B cell responses leading some to take a rather nihilist view of their clinical value [82]. Nevertheless, extensive literature has consistently shown that $\mathrm{ANuA}$ do have meaningful clinical correlates. ANuA and anti-dsDNA autoantibodies have been associated with lupus disease activity and higher SLEDAI scores [4, 26, 80, 81, 8389] (see Table 1). The reported prevalence of ANuA in SLE ranged from $50 \%$ to $100 \%[57,90,91]$ and the corresponding specificity between $90 \%$ and $99 \%$ [26-29, 57, 85, 86, 89, 90, 92-94]. A review of ANuA and anti-dsDNA autoantibodies showed greater diagnostic sensitivity for ANuA (59.9\%) than for anti-dsDNA (52.4\%), with a comparable specificity (94.9\% versus $94.2 \%$, resp.) (reviewed in [8]). The difference between the various studies is attributed to the makeup of the clinical cohorts but especially to technical issues such as antigen purification and the adopted cutoff. In a study by Kim et al. [95], the sensitivity of ANuA in SLE was 98.8\% and the specificity was $78.3 \%$. By comparison, Su et al. [96] reported that the sensitivity and specificity of ANuA in SLE were $61.8 \%$ and $97.6 \%$, respectively, and Simón et al. [85] reported that ANuA had a sensitivity of $100 \%$ and specificity of $97 \%$ for SLE diagnosis. In a South African study, Tikly et al. [97] reported that the sensitivity, specificity, positive predictive value, and negative predictive value of ANuA were 45.3\%, 94.3\%, 88.6\%, and $63.6 \%$, respectively. In this study, the presence of ANuA was strongly associated with anti-dsDNA antibodies $(\mathrm{OR}=$ 3.4, $P<0.0005)$ and anti-histone antibodies $(\mathrm{OR}=15.7$, 
$P<0.00001)$. Ghillani-Dalbin et al. [98] studied 1696 patients with various autoimmune diseases and reported that $78 \%$ of SLE were positive for ANuA while $43 \%$ in the SLE group were positive for ANuA and negative for anti-ds-DNA antibodies, indicating that $\mathrm{ANuA}$ is an independent biomarker in SLE. Cairns et al. [28] reported that $\mathrm{ANuA}$ was positive in 61 of 95 (64\%) patients with SLE, none of 95 healthy controls, none of 28 fibromyalgia patients, and in only 2 of 48 (4\%) rheumatoid arthritis (RA) controls. In a study of 131 SLE patients by Düzgün et al. [6], 72 (54.9\%) were seropositive for ANuA, which was significantly higher than only 3 of $74(4 \%)$ patients with RA while none of the patients with scleroderma and 50 healthy individuals were seropositive. The sensitivity and specificity of ANuA in SLE were 83.6\% and $70 \%$, respectively. $38.9 \%$ of these SLE patients had renal involvement. Among these patients, ANuA positivity and anti-dsDNA were $74.5 \%$ and $78.4 \%$, respectively, and ANuA were found to be $31.4 \%$ positive in SLE patients lacking antidsDNA antibody. In a Korean study, 98 of 129 patients (76\%) with SLE presented ANuA, and $15(60 \%)$ patients had ANuA among the 25 patients without anti-dsDNA antibodies [26].

At the clinical interface, ANuA are predominantly associated with renal involvement [26-29, 57, 85] although hematological involvement or arthritis, malar rash, pleuritis, and oral ulcers have also been observed [85]. Another study reported that the frequency of $\mathrm{ANuA}$ in patients with active SLE is similar to that for anti-dsDNA antibodies $[27,35]$. Of note, ANuA are positively correlated with anti-ds-DNA antibodies titers $[26,28,29,93]$. The clinical value and serological independence of ANuA was highlighted by data showing that $11 \%$ to $51 \%$ of ANuA positive sera did not have anti-dsDNA antibodies [26, 28, 57, 94, 96]. Amoura et al. [27] showed a correlation between ANuA and disease activity only for the IgG3, as well as for the IgG/IgM ratio, taking into consideration that IgM-class anti-dsDNA antibodies seem to have a protective role in autoimmune nephropathy $[12,99]$. In a more recent study by Villalta et al. [100] 200 SLE patients with glomerulonephritis showed significantly elevated levels of IgA anti-dsDNA, anti-dsDNA IgG/IgM, and IgA/IgM ratios than patients without renal disease. In a report by Souza et al. [101], ANuA were more prevalent in active SLE patients $(74.2 \%)$ than in inactive SLE (11.7\%). In this study, $\mathrm{ANuA}$ also correlated with disease activity and renal damage but were also found in a proportion of sera that did not have anti-dsDNA antibodies. They also observed that $\mathrm{ANuA}$ were not found in cutaneous lupus erythematosus but were helpful in supporting the diagnosis of DIL, especially lupus related to procainamide, quinidine, and hydralazine exposure. Andreoli et al. [102] studied a cohort of 105 patients with primary anti-phospholipid antibody syndrome (PAPS) of which $77 \%$ were positive for $\mathrm{ANuA}$, whereas mediumhigh titres were only detected in $46 \%$. They concluded that $\mathrm{ANuA}$ were more frequently detected in PAPS and lupus like disease, although no relationship with clinical/serological features was found, except for a weak correlation with antidsDNA antibodies. An intriguing report by Bossuyt et al. [103] indicted that ANuA in the absence of anti-dsDNA can be used as a serological discriminator to identify patients with TNP-alpha inhibitor related ANA.
Some studies have explored the presence of ANuA in the context of relevant circulating autoantigens. For example, significantly higher levels of nucleosomes were found in plasma of $13 / 58$ (22.4\%) SLE patients as compared to healthy individuals [104]. Similar results were obtained using a highly sensitive Picogreen assay (Life Technologies), to quantify DNA in sera of SLE patients [105]. Curiously, none of the 13 patients with elevated levels of circulating DNA as detected by Picogreen had detectable ANuA or anti-dsDNA antibodies. Interestingly, Amoura et al. [104] demonstrated that there was an inverse correlation between DNA concentration, ANuA, and anti-dsDNA antibodies. Derksen et al. [77] measured DNA levels in circulating immune complexes by a quantitative immunochemical assay and found a decrease in DNA concentration during severe flares of SLE and an inverse correlation between DNA levels in immune complexes and anti-dsDNA antibody concentrations measured by CLIFT, ELISA, plasmid DNAbased assay, and Farr assay. A similar inverse relationship between DNA and anti-dsDNA antibodies in plasma from SLE patients was also observed by McCoubrey-Hoyer et al. [106], although many patients had high levels of plasma DNA and anti-dsDNA antibodies without clinical nephritis. This suggests that factors other than simply the presence of ANuA and/or anti-dsDNA antibodies might be important in the initiation and perpetuation of glomerular damage in SLE. In another study, Jørgensen et al. [107] demonstrated an inverse correlation between anti-dsDNA antibodies and the DNA concentration (measured by quantitative PCR) in the circulation in both murine and human serum samples of SLE. High titer of anti-DNA antibodies in human sera correlated with reduced levels of circulating chromatin and in lupus prone mice with deposition within glomeruli. The inverse correlation between DNA concentration and anti-dsDNA antibodies perhaps reflected antibody-dependent deposition of immune complexes during the development of lupus nephritis in autoimmune lupus prone mice. Williams et al. [108] demonstrated that the levels of circulating nucleosomes were raised in SLE patients with active central nervous system disease and renal involvement. However, this is in contrast to previous reports from Derksen et al. showing decreased levels of circulating nucleosomes during flares of the disease [77].

\section{Juvenile SLE (JSLE)}

In children, anti-dsDNA antibody testing was slightly more sensitive than $\mathrm{ANuA}$ (66.5\% versus $64.1 \%$ ), while specificity slightly favored ANuA (98.8\% versus $97.1 \%$ ). However, ANuA displayed a more relevant predictive value than anti-dsDNA antibodies (reviewed in [8]). In a study by Keusseyan et al. [109], anti-nucleosome core particle and anti-chromatin antibodies exhibited high specificity for JSLE but had a similar frequency in active and inactive disease. They also observed that anti-chromatin and IgG/IgG3 anti-nucleosome core particle serum levels did not differ between active and inactive JSLE. Disease activity correlated with anti-dsDNA antibodies but not with antibodies to other chromatin components. 
Notably, anti-nucleosome antibodies in the absence of antidsDNA were observed in $14 \%$ of their patients.

Campos et al. [110] studied ANuA and anti-dsDNA by ELISA in 74 patients with JSLE and 64 normal controls. The presence of ANuA was significantly associated with higher SLEDAI scores, malar erythema, hemolytic anemia, antidsDNA, and low complement levels, but not with renal manifestations. In a cohort of 67 JSLE patients, Jesus et al. [111] observed a higher frequency of ANuA and anti-dsDNA antibodies (48\% and 69\%, resp.) as compared to controls although anti-dsDNA was associated with higher disease activity scores. Wu et al. [112] compared the serum levels of ANuA in 30 JSLE patients by ELISA to 29 adult SLE patients, 30 healthy controls, 21 juvenile idiopathic arthritis, and 23 Henoch-Schonlein purpura patients as autoimmune disease controls. The mean ANuA titer in the JSLE patients was higher than those of adult SLE patients, normal and disease controls. The prevalence of both ANuA (90\%) and anti-dsDNA (76.7\%) in JSLE patients was higher than that in adult SLE patients (58.6\% and $48.3 \%$ ). A positive correlation was demonstrated between ANuA and anti-dsDNA as well as the SLEDAI scores and an inverse correlation with C3 complement in pediatric and adult patients.

\section{Future Areas of Interest}

A number of more recent observations have significant importance in the field of anti-chromatin antibodies. This includes a reinvigorated study of HMG proteins triggered by newer observations on the role of HMGB1 in inflammation and the intriguing evidence that the formation of DNA extracellular traps (NETs) and extracellular microvesicles may provide other vehicles by which inflammatory and immunogenic components of chromatin can be released into the extracellular environment. Although not discussed in detail here, recent evidence suggests that the use of nucleosomal peptides as tolerogens may be a successful approach to suppressing certain aspects of lupus pathogenesis and could lead to the design of novel therapeutics [113].

8.1. High Mobility Group Proteins. High mobility group (HMG) proteins are operationally defined by their extractability from chromatin in $0.35 \mathrm{M} \mathrm{NaCl}$ and their solubility in $5 \%$ perchloric acid (PCA) and $2 \%$ trichloroacetic acid (TCA) $[114,115]$. As potential autoantigens, HMG's are interesting proteins because they are highly amphipathic, with both basic and acidic domains, and they have a relatively high content of proline $[114,115]$. The five main families of mammalian HMG proteins are designated HMGA, HMGB, HMGN, and SOX and TYCF transcription factors (Table 2) [116]. Each of these proteins has been shown to have unique chromatin-binding motifs and characteristics. For example, HMGA contains an AT hook; HMGB contains a HMG box domain; HMGN (including HMG-14/HMGN1 and HMG-17/HMGN2) contains a nucleosomal binding domain. There is evidence that HMG-14 and HMG-17 are preferentially associated with transcriptionally active chromatin [117, 118]. HMGN1/HMG-14 and HMGN2/HMG-17 bind to nucleosomal core histones of transcriptionally active chromatin $[119,120]$. In comparison, HMGB1/HMG-1 and HMGB2/HMG-2 are associated with internucleosomal DNA and appear to be evenly distributed in active and nonactive genes [115, 121].

Dating to the seminal studies of Bustin et al. in 1982 [122], HMG antibodies have been reported in SLE [122-124], mixed connective tissue disease [122], juvenile idiopathic arthritis (JIA) [125-128], canine lupus [129], DIL [130], systemic sclerosis [131], other systemic autoimmune rheumatic diseases [132], primary pulmonary hypertension [133], inflammatory bowel disease [134-136], primary biliary cirrhosis [137], type I diabetes [138], autoimmune hepatitis [139], septic shock [140], and liver transplant patients (see Table 2 for more details) $[141,142]$.

In a study of sera from 42 DIA patients, we found reactivity with $\mathrm{HMG}$ proteins 14 and/or 17 in $67 \%$ of the sera by immunoblotting assays and in $58 \%$ by an ELISA [130]. The slightly lower percentage in the ELISA may be explained in part by the high cut-off value (mean $+3 S D)$ for the ELISA. Some difference in binding might also be expected because of a different conformation and orientation of proteins on the solid matrix of the two assays. Nevertheless, there was correlation between high absorbance values obtained by ELISA and strongly positive immunoblots. By comparison, reactivity with HMG-1 and/or HMG-2 was observed in only 9/42 (21\%) of the DIA sera, although anti-HMG antibodies were found in patients from each drug group with the exception of a serum from a patient treated with alpha methyldopa [130]. Because the prevalence of anti-HMG antibodies in symptomatic DIL was similar to that in asymptomatic PA- or INH-treated patients, anti-HMG antibodies do not appear to correlate with disease manifestations. Other studies reported autoantibodies to HMG-17 in 10/29 (34\%) SLE sera [122] and in $47 \%$ of pauciarticular onset JRA [126] and antibodies to HMG-1 and HMG-2 in 10\% of SLE [122] and 39\% of JRA patients [125]. Another report found that $6 \%$ and $18 \%$ of sera from canine lupus reacted with HMG-1 and HMG-2, respectively, but no antibodies bound to HMG-14 and HMG17 [129].

Until the last decade, one of the HMG proteins, HMGB1, was primarily regarded as a DNA-binding protein that participated in chromatin structure and transcriptional regulation $[143,144]$. However, HMGB1 gained particular interest in the last decade after it was shown that it had a proinflammatory role in endotoxin lethality in mice and in sepsis [145] after its release from damaged or necrotic cells $[146,147]$. HMGB1 is a ubiquitous and abundant chromatin component, and it is currently well known as one of the damage-associated molecular pattern molecules (DAMPs) interacting with the receptor for advanced glycation end product (RAGE), toll-like receptor (TLR)2, TLR4, and TLR9 (reviewed in $[146,148,149])$. The proinflammatory roles of HMGB1 have been reported in acute lung inflammation [150], atherosclerosis, and restenosis after vascular damage [151], hepatic injury after murine liver ischemia reperfusion [152], acute pancreatitis [153], rheumatoid arthritis [154], pulmonary fibrosis [155], cerebral ischemia [156], Kawasaki disease [157], cold ischemia/reperfusion-induced inflammation [158], acute appendicitis [159], systemic inflammatory 
TABLE 2: High mobility group proteins (HMG): classification, nomenclature, and autoimmunity.

\begin{tabular}{|c|c|c|c|}
\hline $\begin{array}{c}\text { HMG family } \\
\text { members }\end{array}$ & Functional domain & Autoantibodies & Other immune reactions \\
\hline $\begin{array}{l}\text { HMGA } \\
\text { HMGA1 } \\
\text { HMGA2 }\end{array}$ & $\begin{array}{l}\text { AT hook } \\
\text { Modulate transcription by altering } \\
\text { chromatin architecture }\end{array}$ & & \\
\hline $\begin{array}{l}\text { HMGB } \\
\text { HMGB1/HMG1* } \\
\text { HMGB2/HMG2* } \\
\text { HMGB3 } \\
\text { HMGB4 }\end{array}$ & $\begin{array}{l}\text { HMG box domain } \\
\text { Bind minor groove of DNA in a } \\
\text { nonsequence-dependent fashion }\end{array}$ & $\begin{array}{l}\text { AIH, SLE, SSc, DIA, JIA, UC, } \\
\text { septic shock, liver transplant } \\
\text { patients }\end{array}$ & $\begin{array}{l}\text { HMGB1: } \\
\text { Proinflammatory mediator. } \\
\text { Perhaps anti-HMGB1 } \\
\text { autoantibodies ameliorate } \\
\text { proinflammatory effects and are } \\
\text { protective }\end{array}$ \\
\hline $\begin{array}{l}\text { HMGN } \\
\text { HMGN1/HMG14* } \\
\text { HMGN2/HMG17 }\end{array}$ & $\begin{array}{l}\text { HMG nucleosomal binding domain } \\
\text { Function in transcription, } \\
\text { replication, DNA repair, alter the } \\
\text { interaction of histone H1 with } \\
\text { nucleosomes to maintain a } \\
\text { decondensed chromatin structure }\end{array}$ & $\begin{array}{l}\text { DIA/DIL, SSc, PPH, SLE, } \\
\text { MCTD }\end{array}$ & \\
\hline $\begin{array}{l}\text { SOX } \\
\text { SDRY } \\
\text { SOXB1 } \\
\text { SOXB2 } \\
\text { SOX-C, -D, -E, -F } \\
\text { SOX13 }\end{array}$ & $\begin{array}{l}\text { Transcription Factors } \\
\text { HMG box with high sequence } \\
\text { similarity to SDRY }\end{array}$ & PBC, AIH, type I diabetes & \\
\hline $\begin{array}{l}\text { TCF } \\
\text { LEBF1 } \\
\text { TCTF1 } \\
\text { TF7L1P } \\
\text { TF7L2P }\end{array}$ & Transcription factors & None published & $\begin{array}{l}\text { Role in control of } \mathrm{T} \text { cell } \\
\text { transcription }\end{array}$ \\
\hline
\end{tabular}

* Older nomenclature HMG1, HMG2, HMG14, HMG17.

AIH: autoimmune hepatitis; DIA: drug-induced autoimmunity, DIL: drug-induced lupus; JIA: juvenile idiopathic arthritis; LEBF: lymphoid enhancer-binding factor 1, MCTD: mixed connective tissue disease; PBC: primary biliary cirrhosis; PPH: primary pulmonary hypertension; SARD: systemic autoimmune rheumatic diseases; SDRY: sex determining region Y; SLE: systemic lupus erythematosus; SOX: Sry-related HMG box; SSc: systemic sclerosis; TCF: transcription factor; TCTF: T cell transcription factor; TF7LP: Transcription factor 7-like Protein; UC: ulcerative colitis.

response syndrome [160, 161], febrile seizures [162], hyperlipidemia [163], preeclampsia [164], and models of liver failure [165-167].

HMGB1 is also secreted from various cell types during activation and/or cell death and may act as a proinflammatory mediator, alone or as part of DNA-containing immune complexes in SLE $[168,169]$. A recent study by Wen et al. [170] concluded that HMGB1 in circulating DNAcontaining immune complexes was crucial for anti-dsDNA $\mathrm{Ab}$ induction and it correlated positively with anti-dsDNA $\mathrm{Ab}$ production in patients with SLE. They also observed that TLR2/MyD88/microRNA-155 (miR-155) pathway was pivotal for HMGB1 to confer anti-dsDNA Ab induction. Recent studies evaluating the role of HMGB1 in LN showed that 21/69 SLE patients with biopsy proven active LN had higher urinary and serum levels of HMGB1 as compared to those without active LN [171]. They also concluded that the serum levels of HMGB1 correlated with SLE disease activity score and, inversely, with levels of the complement components C3 and C4 [171]. Similarly, a study of 35 active SLE LN patients showed that renal tissue expression and serum levels of HMGB1 were increased in LN and HMGB1 failed to decrease in serum and tissue after immunosuppressive therapy, a feature reflecting persistent inflammatory activity [171]. Santoro et al. [172] revealed a high prevalence of autoantibodies to HMG protein structure specific recognition protein I (SSRP1) in $28.8 \%$ of patients with SLE as compared to other autoimmune disorders. In a study by Li et al. [173] HMGB1 correlated with disease activity, low complements, and disrupted cytokine homeostasis. In cutaneous lupus, increased amounts of cytoplasmic and extracellular HMGB1 were detected within the lesional skin together with high expression levels of TNFa and IL-1b [8]. Future research on HMG proteins promises to yield other related novel biomarkers $[154,157,162,164]$ and therapeutic targets in SLE $[153,165,174-178]$.

Last, a few reports have implicated autoantibodies to sex related Y HMG box (SOX) proteins in type I diabetes [138] and anti-SOX13 in primary biliary cirrhosis, autoimmune hepatitis, and other diseases [137]. In this latter study, antiSOX13 was detected in $18 \%$ of patients with PBC, $13 \%$ with autoimmune hepatitis, and $18 \%$ with type 1 diabetes, at lower frequencies in other conditions including the multisystem autoimmune diseases, SLE, and rheumatoid arthritis, but in only $1 \%$ of normal sera. More studies are required to 
validate these studies and determine their sensitivity and specificity.

Observations that there is a high frequency of antibodies to the HMG proteins associated with nucleosomes add further evidence implicating the nucleosome or nucleosomal subunits as immunogens. Furthermore, observations that the most common autoantibody targets in human diseases are HMGN1/HMG-14 and HMGN2/HMG-17, which are preferentially associated with the nucleosomes of transcriptionally active chromatin, suggests that functionally and structurally distinct forms of nucleosomes are the inciting immunogens in autoimmune disease.

8.2. DNA Neutrophil Extracellular Traps (Nets). Neutrophils kill certain extracellular pathogens by releasing their highly decondensed chromatin as extracellular traps (NETs) [179]. The impact of NETs is derived from the combined antimicrobial activities of granular components, histones, and some cytoplasmic proteins (reviewed in $[180,181]$ ) and the release of danger signals or DAMPs from disrupted cells and tissues [182]. The various methods of NET quantification include microscopy [179, 183-185] and DNA detection either with membrane impermeable DNA dyes [179] or by staining the DNA in the supernatant after releasing the NETs with a mild nuclease treatment $[181,186]$. The role of NETs in autoimmune diseases has been the subject of recent reviews $[187,188]$. Neutrophils isolated from SLE patients are more prone to making NETs, particularly in response to antibody complexes [189-192]. As discussed throughout this review, SLE is characterized by autoantibodies directed against DNA, chromatin, and DNA-associated proteins, all potential components of NETs. Recent evidence points to an imbalance between NET formation and NET clearance in SLE $[185,190-192]$ and decreased NET degradation has been associated with complement activation [193] and correlated with a subset of SLE patients with renal disease and attended by DNasel inhibitors and anti-NET antibodies [185]. There is also preliminary evidence that the nuclear material externalized in NETs has antiviral activity $[194,195]$ and is involved in vasculopathies [196, 197], sterile inflammation [198], and promote autoantibody formation in SLE [191]. However, further studies are needed to understand the complex role of these NETs in triggering an autoimmune response and/or inflammation that would aid in predicting disease onset or flares and facilitate the development of compounds that selectively target the deleterious aspects triggered by these macromolecular lattices.

\section{Summary}

(1) ANuA and anti-dsDNA are independent and complementary biomarkers that have value in the diagnosis and disease activity assessment of SLE. ANuA are specially a useful marker in the diagnosis of SLE patients who are anti-dsDNA negative. ANuA and anti-dsDNA both are associated with disease flare and lupus nephritis.
(2) In general, ANuA have equal specificity but higher sensitivity, positive likelihood ratio, and diagnostic odds ratio than anti-dsDNA antibodies for the diagnosis of SLE.

(3) The emergence of newer immunoassays for the detection of antibodies to chromatin components requires ongoing pre- and postmarketing evaluation. Standardization of nomenclature and assay performance is a desirable goal.

(4) The renaissance of autoantibodies to HMG proteins and their relationship to other chromatin components including nucleosomes and DNA NETs are beginning to weave interesting paradigms in autoimmunity that requires further investigation. Circulating antiHMGB1 and HMGB1 levels may be useful when assessing the protective effects of autoantibodies.

\author{
Abbreviations \\ ALBIA: Addressable laser bead immunoassays \\ ANuA: Anti-nucleosome autoantibodies \\ CLIFT: Crithidia luciliae immunofluorescence test \\ DAMPS: Damage-associated molecular patterns \\ dsDNA: Double stranded DNA \\ EliA: Fluoroenzyme immunoassay \\ ELISA: Enzyme-linked immune assays \\ HMG: High mobility group \\ JIA: Juvenile inflammatory arthritis \\ JSLE: Juvenile systemic lupus erythematosus \\ MCTD: Mixed connective tissue disease \\ NETs: Neutrophil extracellular traps \\ PAPS: Primary anti-phospholipid antibody syndrome \\ RA: Rheumatoid arthritis \\ SLE: $\quad$ Systemic lupus erythematosus \\ SOX: $\quad$ Sex related Y HMG box \\ ssDNA: Single stranded DNA.
}

\section{Conflict of Interests}

Sonal Mehra has no conflict of interests to declare. Marvin J. Fritzler is a paid consultant, has received honoraria, and has received gifts in kind from ImmunoConcepts Inc. (Sacramento, CA, USA), Bio-Rad (Hercules, CA, USA), INOVA Diagnostics (San Diego, CA, USA), Euroimmun GmbH (Lubeck, Germany), and Dr. Fooke Laboratorien $\mathrm{GmbH}$ (Neuss, Germany).

\section{References}

[1] K. Luger, A. W. Mäder, R. K. Richmond, D. F. Sargent, and T. J. Richmond, "Crystal structure of the nucleosome core particle at 2.8 Å resolution,” Nature, vol. 389, no. 6648, pp. 251-260, 1997.

[2] P. R. Walker and M. Sikorska, "Chromatin structure. Further evidence against the existence of a beaded subunit for the 30nm fiber," Journal of Biological Chemistry, vol. 262, no. 25, pp. 12218-12222, 1987.

[3] R. L. Rubin and M. J. Fritzler, "Antibodies to histones and nucleosome-related antigens," in Dubois' Lupus Erythematosus, D. J. 
Wallace and B. H. Hahn, Eds., pp. 464-486, Lippincott Williams \& Wilkins, Philadelphia, Pa, USA, 7 edition, 2007.

[4] R. W. Burlingame and R. Cervera, "Anti-chromatin (antinucleosome) autoantibodies," Autoimmunity Reviews, vol. 1, no. 6, pp. 321-328, 2002.

[5] R. W. Burlingame, "Recent advances in understanding the clinical utility and underlying cause of antinucleosome (antichromatin) autoantibodies," Clinical and Applied Immunology Reviews, vol. 4, no. 5, pp. 351-366, 2004.

[6] N. Düzgün, M. Şahin, Y. Genç, and H. Tutkak, "Antinucleosome antibodies and systemic lupus erythematosus," Annals of the New York Academy of Sciences, vol. 1109, pp. 421-428, 2007.

[7] I. Půtová, C. Dostal, and R. Becvar, "Prevalence of antinucleosome antibodies by enzyme-linked immunosorbent assays in patients with systemic lupus erythematosus and other autoimmune systemic diseases," Annals of the New York Academy of Sciences, vol. 1109, pp. 275-286, 2007.

[8] N. Bizzaro, D. Villalta, D. Giavarina, and R. Tozzoli, "Are anti-nucleosome antibodies a better diagnostic marker than anti-dsDNA antibodies for systemic lupus erythematosus? A systematic review and a study of metanalysis," Autoimmunity Reviews, vol. 12, pp. 97-106, 2012.

[9] G. Riemekasten and B. H. Hahn, "Key autoantigens in SLE," Rheumatology, vol. 44, no. 8, pp. 975-982, 2005.

[10] V. Racanelli, M. Prete, G. Musaraj, F. Dammacco, and F. Perosa, "Autoantibodies to intracellular antigens: generation and pathogenetic role," Autoimmunity Reviews, vol. 10, no. 8, pp. 503-508, 2011.

[11] V. N. Buneva, M. A. Krasnorutskii, and G. A. Nevinsky, "Natural antibodies to nucleic acids," Biochemistry, vol. 78, pp. 127-143, 2013.

[12] Y. Shoenfeld and E. Toubi, "Protective autoantibodies: role in homeostasis, clinical importance, and therapeutic potential," Arthritis and Rheumatism, vol. 52, no. 9, pp. 2599-2606, 2005.

[13] Y. Shapira, B.-S. P. Katz, B. Gilburd et al., "Geographical differences in autoantibodies and anti-infectious agents antibodies among healthy adults," Clinical Reviews in Allergy and Immunology, vol. 42, pp. 154-162, 2012.

[14] J. B. Winfield, I. Fairferman, and D. Koffler, "Avidity of anti DNA antibodies in serum and IgG glomerular eluates from patients with systemic lupus erythematosus," Journal of Clinical Investigation, vol. 59, no. 1, pp. 90-96, 1977.

[15] R. J. T. Smeenk, "Detection of antibodies to dsDNA: current insights into its relevance," Clinical and Experimental Rheumatology, vol. 20, no. 3, pp. 294-300, 2002.

[16] R. J. T. Smeenk, J. H. M. Berden, and A. J. G. Swaak, "dsDNA autoantibodies," in Autoantibodies, J. B. Peter and Y. Shoenfeld, Eds., pp. 227-236, Elsevier Science, Amsterdam, The Netherlands, 1996.

[17] M. C. Hochberg, "Updating the American College of Rheumatology revised criteria for the classification of systemic lupus erythematosus," Arthritis and Rheumatism, vol. 40, no. 9, p. $1725,1997$.

[18] M. Petri, A. M. Orbai, G. S. Alarcon et al., "Derivation and validation of the systemic lupus international collaborating clinics classification criteria for systemic lupus erythematosus," Arthritis \& Rheumatology, vol. 64, pp. 2677-2686, 2012.

[19] R. Gualtierotti, M. Biggioggero, A. E. Penatti, and P. L. Meroni, "Updating on the pathogenesis of systemic lupus erythematosus," Autoimmunity Reviews, vol. 10, no. 1, pp. 3-7, 2010.
[20] L. M. Stinton, S. G. Barr, L. A. Tibbles et al., "Autoantibodies in lupus nephritis patients requiring renal transplantation," Lupus, vol. 16, no. 6, pp. 394-400, 2007.

[21] M. López-Hoyos, R. Cabeza, V. M. Martínez-Taboada et al., "Clinical disease activity and titers of anti-dsDNA antibodies measured by an automated immunofluorescence assay in patients with systemic lupus erythematosus," Lupus, vol. 14, no. 7, pp. 505-509, 2005.

[22] E. S. Mortensen, K. A. Fenton, and O. P. Rekvig, "Lupus nephritis: the central role of nucleosomes revealed," American Journal of Pathology, vol. 172, no. 2, pp. 275-283, 2008.

[23] N. Seredkina, J. van der Vlag, J. Berden, E. Mortensen, and O. P. Rekvig, "Lupus nephritis: enigmas, conflicting models and an emerging concept," Molecular Medicine, vol. 19, pp. 161-169, 2013.

[24] Z. Amoura, J.-C. Piette, J.-F. Bach, and S. Koutouzov, “The key role of nucleosomes in lupus," Arthritis \& Rheumatism, vol. 42, pp. 833-843, 1999.

[25] J. H. M. Berden, "Lupus nephritis," Kidney International, vol. 52, no. 2, pp. 538-558, 1997.

[26] D.-J. Min, S.-J. Kim, S.-H. Park et al., "Anti-nucleosome antibody: significance in lupus patients lacking anti-doublestranded DNA antibody," Clinical and Experimental Rheumatology, vol. 20, no. 1, pp. 13-18, 2002.

[27] Z. Amoura, S. Koutouzov, H. Chabre et al., "Presence of antinucleosome autoantibodies in a restricted set of connective tissue diseases: antinucleosome antibodies of the IgG3 subclass are markers of renal pathogenicity in systemic lupus erythematosus," Arthritis \& Rheumatology, vol. 43, pp. 76-84, 2000.

[28] A. P. Cairns, S. A. McMillan, A. D. Crockard et al., "Antinucleosome antibodies in the diagnosis of systemic lupus erythematosus," Annals of the Rheumatic Diseases, vol. 62, no. 3, pp. 272273, 2003.

[29] R. Cervera, O. Viñas, M. Ramos-Casals et al., "Anti-chromatin antibodies in systemic lupus erythematosus: a useful marker for lupus nephropathy," Annals of the Rheumatic Diseases, vol. 62, no. 5, pp. 431-434, 2003.

[30] O. A. Gutiérrez-Adrianzén, S. Koutouzov, R. M. Salani Mota, M. M. das Chagas Medeiros, J.-F. Bach, and H. de Holanda Campos, "Diagnostic value of anti-nucleosome antibodies in the assessment of disease activity of systemic lupus erythematosus: a prospective study comparing anti-nucleosome with antidsDNA antibodies," Journal of Rheumatology, vol. 33, no. 8, pp. 1538-1544, 2006.

[31] P. Decker, "Nucleosome autoantibodies," Clinica Chimica Acta, vol. 366, no. 1-2, pp. 48-60, 2006.

[32] P. Decker, H. Singh-Jasuja, S. Haager, I. Kötter, and H.-G. Rammensee, "Nucleosome, the main autoantigen in systemic lupus erythematosus, induces direct dendritic cell activation via a MyD88-independent pathway: consequences on inflammation," Journal of Immunology, vol. 174, no. 6, pp. 3326-3334, 2005.

[33] B. D. Stollar, "Antibodies to DNA," CRC Critical Reviews in Biochemistry, vol. 20, no. 1, pp. 1-36, 1986.

[34] B. D. Stollar, "The origin and pathogenic role of anti-DNA autoantibodies," Current Opinion in Immunology, vol. 2, no. 4, pp. 607-612, 1990.

[35] S. Koutouzov, A. L. Jeronimo, H. Campos, and Z. Amoura, "Nucleosomes in the pathogenesis of systemic lupus erythematosus," Rheumatic Disease Clinics of North America, vol. 30, no. 3, pp. 529-558, 2004. 
[36] J. W. C. Dieker, J. van der Vlag, and J. H. M. Berden, “Triggers for anti-chromatin autoantibody production in SLE," Lupus, vol. 11, no. 12 , pp. 856-864, 2002.

[37] E. S. Mortensen and O. P. Rekvig, "Nephritogenic potential of anti-DNA antibodies against necrotic nucleosomes," Journal of the American Society of Nephrology, vol. 20, no. 4, pp. 696-704, 2009.

[38] K.-Y. Su and D. S. Pisetsky, "The role of extracellular DNA in autoimmunity in SLE," Scandinavian Journal of Immunology, vol. 70, no. 3, pp. 175-183, 2009.

[39] D. S. Pisetsky, "The origin and properties of extracellular DNA: from PAMP to DAMP," Clinical Immunology, vol. 144, pp. 3240, 2012.

[40] A. J. Ullal, C. F. Reich III, M. Clowse et al., "Microparticles as antigenic targets of antibodies to DNA and nucleosomes in systemic lupus erythematosus," Journal of Autoimmunity, vol. 36, no. 3-4, pp. 173-180, 2011.

[41] J. R. Dye, A. J. Ullal, and D. S. Pisetsky, "The role of microparticles in the pathogenesis of rheumatoid arthritis and SLE," Scandinavian Journal of Immunology, vol. 78, pp. 140-148, 2013.

[42] C. C. van Bavel, J. Dieker, S. Muller et al., "Apoptosis-associated acetylation on histone $\mathrm{H} 2 \mathrm{~B}$ is an epitope for lupus autoantibodies," Molecular Immunology, vol. 47, no. 2-3, pp. 511-516, 2009.

[43] C. C. van Bavel, J. W. Dieker, Y. Kroeze et al., "Apoptosisinduced histone $\mathrm{H} 3$ methylation is targeted by autoantibodies in systemic lupus erythematosus," Annals of the Rheumatic Diseases, vol. 70, no. 1, pp. 201-207, 2011.

[44] W. Emlen, V. M. Holers, W. P. Arend, and B. Kotzin, "Regulation of nuclear antigen expression on the cell surface of human monocytes," Journal of Immunology, vol. 148, no. 10, pp. 30423048, 1992.

[45] R. W. Burlingame, R. L. Rubin, R. S. Balderas, and A. N. Theofilopoulos, "Genesis and evolution of antichromatin autoantibodies in murine lupus implicates T-dependent immunization with self antigen," Journal of Clinical Investigation, vol. 91, no. 4, pp. 1687-1695, 1993.

[46] D. Laderach, S. Koutouzov, J.-F. Bach, and A. M. Yamamoto, "Concomitant early appearance of anti-ribonucleoprotein and anti-nucleosome antibodies in lupus prone mice," Journal of Autoimmunity, vol. 20, no. 2, pp. 161-170, 2003.

[47] C. Mohan, S. Adams, V. Stanik, and S. K. Datta, "Nucleosome: a major immunogen for pathogenic autoantibody-inducing $\mathrm{T}$ cells of lupus," Journal of Experimental Medicine, vol. 177, no. 5, pp. 1367-1381, 1993.

[48] A. Lartigue, P. Courville, I. Auquit et al., "Role of TLR9 in anti-nucleosome and anti-DNA antibody production in lpr mutation-induced marine lupus," Journal of Immunology, vol. 177, no. 2, pp. 1349-1354, 2006.

[49] A. Rosen and L. Casciola-Rosen, "Clearing the way to mechanisms of autoimmunity," Nature Medicine, vol. 7, no. 6, pp. 664665, 2001

[50] C. F. Reich III and D. S. Pisetsky, “The content of DNA and RNA in microparticles released by Jurkat and HL-60 cells undergoing in vitro apoptosis," Experimental Cell Research, vol. 315, no. 5, pp. 760-768, 2009.

[51] M. J. Fritzler and E. M. Tan, "Antibodies to histones in drug-induced and idiopathic lupus erythematosus," Journal of Clinical Investigation, vol. 62, no. 3, pp. 560-567, 1978.

[52] N. F. Rothfield and B. D. Stollar, "The relation of immunoglobulin class, pattern of anti-nuclear antibody, and complementfixing antibodies to DNA in sera from patients with systemic lupus erythematosus," Journal of Clinical Investigation, vol. 46, no. 11, pp. 1785-1794, 1967.

[53] J. P. Portanova, R. E. Arndt, E. M. Tan, and B. L. Kotzin, "Anti-histone antibodies in idiopathic and drug-induced lupus recognize distinct intrahistone regions," Journal of Immunology, vol. 138, no. 2, pp. 446-451, 1987.

[54] R. W. Burlingame and R. L. Rubin, "Drug-induced antihistone autoantibodies display two patterns of reactivity with substructures of chromatin," Journal of Clinical Investigation, vol. 88, no. 2, pp. 680-690, 1991.

[55] J. van der Vlag and J. H. M. Berden, "Lupus nephritis: role of antinucleosome autoantibodies," Seminars in Nephrology, vol. 31, no. 4, pp. 376-389, 2011.

[56] Z. Amoura, H. Chabre, S. Koutouzov et al., "Nucleosomerestricted antibodies are detected before anti-dsDNA and/or antihistone antibodies in serum of MRL-Mp lpr/lpr and $+/+$ mice, and are present in kidney eluates of lupus mice with proteinuria," Arthritis and Rheumatism, vol. 37, no. 11, pp. 1684$1688,1994$.

[57] R. W. Burlingame, M. L. Boey, G. Starkebaum, and R. L. Rubin, "The central role of chromatin in autoimmune responses to histones and DNA in systemic lupus erythematosus," Journal of Clinical Investigation, vol. 94, no. 1, pp. 184-192, 1994.

[58] H. Bagavant, U. S. Deshmukh, F. Gaskin, and S. M. Fu, "Lupus glomerulonephritis revisited 2004: autoimmunity and endorgan damage," Scandinavian Journal of Immunology, vol. 60, no. 1, pp. 52-63, 2004.

[59] U. Wellmann, M. Letz, M. Herrmann, S. Angermüller, J. R. Kalden, and T. H. Winkler, "The evolution of human anti-double-stranded DNA autoantibodies," Proceedings of the National Academy of Sciences of the United States of America, vol. 102, no. 26, pp. 9258-9263, 2005.

[60] L. E. Munoz, U. S. Gaipl, and M. Herrmann, "Predictive value of anti-dsDNA autoantibodies: importance of the assay," Autoimmunity Reviews, vol. 7, no. 8, pp. 594-597, 2008.

[61] D. Alarcon-Segovia, A. Ruiz-Arguelles, and E. Fishbein, "Antibody to nuclear ribonucleoprotein penetrates live human mononuclear cells through Fc receptors," Nature, vol. 271, no. 5640, pp. 67-69, 1978.

[62] D. Alarcón-Segovia, A. Ruiz-Argüelles, and L. Llorente, "Broken dogma: penetration of autoantibodies into living cells," Immunology Today, vol. 17, no. 4, pp. 163-164, 1996.

[63] C. Putterman, "New approaches to the renal pathogenicity of anti-DNA antibodies in systemic lupus erythematosus," Autoimmunity Reviews, vol. 3, no. 2, pp. 7-11, 2004.

[64] A.-M. Rouquette and C. Desgruelles, "Detection of antibodies to dsDNA: an overview of laboratory assays," Lupus, vol. 15, no. 7, pp. 403-407, 2006.

[65] M. Mahler and M. J. Fritzler, "Anti-dsDNA antibody testing in the clinic: farr or ELISA? Commentay," Nature Clinical Practice Rheumatology, vol. 3, no. 2, pp. 72-73, 2007.

[66] M. J. Fritzler, "Advances and applications of multiplexed diagnostic technologies in autoimmune diseases," Lupus, vol. 15, no. 7, pp. 422-427, 2006.

[67] S. Desplat-Jego, N. Bardin, B. Larida, and M. Sanmarco, "Evaluation of the BioPlex 2200 ANA screen for the detection of antinuclear antibodies and comparison with conventional methods," Annals of the New York Academy of Sciences, vol. 1109, pp. 245-255, 2007.

[68] P. J. Utz, "Multiplexed assays for identification of biomarkers and surrogate markers in systemic lupus erythematosus," Lupus, vol. 13, no. 5, pp. 304-311, 2004. 
[69] P. Riboldi, M. Gerosa, G. Moroni et al., "Anti-DNA antibodies: a diagnostic and prognostic tool for systemic lupus erythematosus?" Autoimmunity, vol. 38, no. 1, pp. 39-45, 2005.

[70] S. Albon, C. Bunn, G. Swana, and Y. Karim, "Performance of a multiplex assay compared to enzyme and precipitation methods for anti-ENA testing in systemic lupus and systemic sclerosis," Journal of Immunological Methods, vol. 365, no. 1-2, pp. 126-131, 2011.

[71] J. G. Hanly, L. Su, V. Farewell, and M. J. Fritzler, “Comparison between multiplex assays for autoantibody detection in systemic lupus erythematosus," Journal of Immunological Methods, vol. 358, no. 1-2, pp. 75-80, 2010.

[72] S. S. Copple, T. B. Martins, C. Masterson, E. Joly, and H. R. Hill, "Comparison of three multiplex immunoassays for detection of antibodies to extractable nuclear antibodies using clinically defined sera," Annals of the New York Academy of Sciences, vol. 1109, pp. 464-472, 2007.

[73] B. B. Suh-Lailam, T. R. Chiaro, K. Wayne Davis, A. R. Wilson, and A. E. Tebo, "Evaluation of a high avidity anti-dsDNA igG enzyme-linked immunosorbent assay for the diagnosis of systemic lupus erythematosus," International Journal of Clinical and Experimental Pathology, vol. 4, no. 8, pp. 748-754, 2011.

[74] A. Ghirardello, D. Villalta, G. Morozzi et al., "Diagnostic accuracy of currently available anti-double-stranded DNA antibody assays. An Italian multicentre study," Clinical and Experimental Rheumatology, vol. 29, no. 1, pp. 50-56, 2011.

[75] A. Antico, S. Platzgummer, D. Bassetti, N. Bizzaro, R. Tozzoli, and D. Villalta, "Diagnosing systemic lupus erythematosus: new-generation immunoassays for measurement of antidsDNA antibodies are an effective alternative to the Farr technique and the Crithidia luciliae immunofluorescence test," Lupus, vol. 19, no. 8, pp. 906-912, 2010.

[76] M. J. Fritzler, A. Wiik, E. M. Tan et al., "A critical evaluation of enzyme immunoassay kits for detection of antinuclear autoantibodies of defined specificities. III. Comparative performance characteristics of academic and manufacturers' laboratories," Journal of Rheumatology, vol. 30, no. 11, pp. 2374-2381, 2003.

[77] R. H. W. M. Derksen, E. J. E. G. Bast, T. Strooisma, and J. W. G. Jacobs, "A comparison between the Farr radioimmunoassay and a new automated fluorescence immunoassay for the detection of antibodies against double stranded DNA in serum," Annals of the Rheumatic Diseases, vol. 61, no. 12, pp. 1099-1102, 2002.

[78] K. Haugbro, J. C. Nossent, T. Winkler, Y. Figenschau, and O. P. Rekvig, "Anti-dsDNA antibodies and disease classification in antinuclear antibody positive patients: the role of analytical diversity," Annals of the Rheumatic Diseases, vol. 63, no. 4, pp. 386-394, 2004.

[79] P. D. Cary, C. Crane-Robinson, E. M. Bradbury, and G. H. Dixon, "Structural studies of the non-histone chromosomal proteins HMG-T and H6 from trout testis," European Journal of Biochemistry, vol. 119, no. 3, pp. 545-551, 1981.

[80] N. Bardin, S. Desplat-Jego, L. Daniel, N. Jourde Chiche, and M. Sanmarco, "BioPlexeU multiplexed system: simultaneous detection of anti-dsDNA and anti-chromatin antibodies in patients with systemic lupus erythematosus," Autoimmunity, vol. 42, no. 1, pp. 63-68, 2009.

[81] N. Bose, X. Wang, M. Gupta, and Q. Yao, "The clinical utility of anti-chromatin antibodies as measured by BioPlex 2200 in the diagnosis of systemic lupus erythematosus versus other rheumatic diseases," International Journal of Clinical and Experimental Medicine, vol. 5, pp. 316-320, 2012.
[82] O. P. Rekvig, J. van der Vlag, and N. Seredkina, "Anti-nucleosome antibodies: a critical reflection on their specificities and diagnostic impact," Arthritis \& Rheumatology, 2014.

[83] C. Grootscholten, J. W. C. Dieker, F. D. McGrath et al., "A prospective study of anti-chromatin and anti-Clq autoantibod-ies in patients with proliferative lupus nephritis treated with cyclophosphamide pulses or azathioprine/ methylprednisolone," Annals of the Rheumatic Diseases, vol. 66, no. 5, pp. 693-696, 2007.

[84] A. Bruns, S. Bläss, G. Hausdorf, G. R. Burmester, and F. Hiepe, "Nucleosomes are major T and B cell autoantigens in systemic lupus erythematosus," Arthritis \& Rheumatology, vol. 43, pp. 2307-2315, 2000.

[85] J. A. Simón, J. Cabiedes, E. Ortiz, J. Alcocer-Varela, and J. Sánchez-Guerrero, "Anti-nucleosome antibodies in patients with systemic lupus erythematosus of recent onset. Potential utility as diagnostic tool and disease activity marker," Rheumatology, vol. 43, no. 2, pp. 220-224, 2004.

[86] G. Schett, J. Smolen, C. Zimmermann et al., “The autoimmune response to chromatin antigens in systemic lupus erythematosus: autoantibodies against histone $\mathrm{H} 1$ are a highly specific marker for SLE associated with increased disease activity," Lupus, vol. 11, no. 11, pp. 704-715, 2002.

[87] H. Julkunen, S. Ekblom-Kullberg, and A. Miettinen, "Nonrenal and renal activity of systemic lupus erythematosus: a comparison of two anti-Clq and five anti-dsDNA assays and complement C3 and C4," Rheumatology International, vol. 32, pp. 2445-2451, 2012.

[88] G. A. Sardeto, L. M. Simas, T. S. Skare, R. M. Nisihara, and S. R. R. Utiyama, "Antinucleosome in systemic lupus erythematosus. A study in a Brazilian population," Clinical Rheumatology, vol. 31, no. 3, pp. 553-556, 2012.

[89] S. Suleiman, D. Kamaliah, A. Nadeem, N. N. Naing, and C. H. Che Maraina, "Anti-nucleosome antibodies as a disease activity marker in patients with systemic lupus erythematosus," International Journal of Rheumatic Diseases, vol. 12, no. 2, pp. 100-106, 2009.

[90] H. Chabre, Z. Amoura, J.-C. Piette, P. Godeau, J.-F. Bach, and S. Koutouzov, "Presence of nucleosome-restricted antibodies in patients with systemic lupus erythematosus," Arthritis and Rheumatism, vol. 38, no. 10, pp. 1485-1491, 1995.

[91] S. Haddouk, M. B. Ayed, S. Baklouti, J. Hachicha, Z. Bahloul, and H. Masmoudi, "Clinical significance of antinucleosome antibodies in Tunisian systemic lupus erythematosus patients," Clinical Rheumatology, vol. 24, no. 3, pp. 219-222, 2005.

[92] Y. Hmida, P. Schmit, G. Gilson, and R. L. Humbel, "Failure to detect antinucleosome antibodies in scleroderma: comment on the article by Amoura et al," Arthritis \& Rheumatology, vol. 46, pp. 280-282, 2002.

[93] A. Ghirardello, A. Doria, S. Zampieri et al., "Antinucleosome antibodies in SLE: a two-year follow-up study of 101 patients," Journal of Autoimmunity, vol. 22, no. 3, pp. 235-240, 2004.

[94] A. Braun, J. Sis, R. Max et al., "Anti-chromatin and anti$\mathrm{Clq}$ antibodies in systemic lupus erythematosus compared to other systemic autoimmune diseases," Scandinavian Journal of Rheumatology, vol. 36, no. 4, pp. 291-298, 2007.

[95] H.-A. Kim, J.-Y. Jeon, G.-S. Choi et al., "The antichromatin antibodies can be useful as a diagnostic tool and disease activity marker of systemic lupus erythematosus in Koreans," Clinical Immunology, vol. 128, no. 2, pp. 277-283, 2008. 
[96] Y. Su, R.-L. Jia, L. Han, and Z.-G. Li, "Role of anti-nucleosome antibody in the diagnosis of systemic lupus erythematosus," Clinical Immunology, vol. 122, no. 1, pp. 115-120, 2007.

[97] M. Tikly, T. Gould, A. A. Wadee, E. Westhuizen, and B. B. N. Mokgethwa, "Clinical and serological correlates of antinucleosome antibodies in South Africans with systemic lupus erythematosus," Clinical Rheumatology, vol. 26, no. 12, pp. 21212125, 2007.

[98] P. Ghillani-Dalbin, Z. Amoura, P. Cacoub et al., "Testing for anti-nucleosome antibodies in daily practice: a monocentric evaluation in 1696 patients," Lupus, vol. 12, no. 11, pp. 833-837, 2003.

[99] T. Witte, "IgM antibodies against dsDNA in SLE," Clinical Reviews in Allergy and Immunology, vol. 34, no. 3, pp. 345-347, 2008.

[100] D. Villalta, N. Bizzaro, N. Bassi et al., "Anti-dsDNA antibody isotypes in systemic lupus erythematosus: IgA in addition to IgG anti-dsDNA help to identify glomerulonephritis and active disease," PLoS ONE, vol. 8, Article ID e71458, 2013.

[101] A. Souza, L. M. da Silva, F. R. Oliveira, A. M. F. Roselino, and P. Louzada-Junior, "Anti-nucleosome and anti-chromatin antibodies are present in active systemic lupus erythematosus but not in the cutaneous form of the disease," Lupus, vol. 18, no. 3, pp. 223-229, 2009.

[102] L. Andreoli, F. Pregnolato, R. W. Burlingame et al., "Antinucleosome antibodies in primary antiphospholipid syndrome: a hint at systemic autoimmunity?" Journal of Autoimmunity, vol. 30, no. 1-2, pp. 51-57, 2008.

[103] X. Bossuyt, J. Frans, A. Hendrickx et al., "Detection of antinucleosome antibodies in a routine clinical laboratory setting," Clinical and Experimental Rheumatology, vol. 26, no. 2, pp. 387388, 2008.

[104] Z. Amoura, J.-C. Piette, H. Chabre et al., "Circulating plasma levels of nucleosomes in patients with systemic lupus erythematosus," Arthritis and Rheumatism, vol. 40, no. 12, pp. 22172225, 1997.

[105] J. A. Chen, S. Meister, V. Urbonaviciute et al., "Sensitive detection of plasma/serum DNA in patients with systemic lupus erythematosus," Autoimmunity, vol. 40, no. 4, pp. 307-310, 2007.

[106] A. McCoubrey-Hoyer, T. B. Okarma, and H. R. Holman, "Partial purification and characterization of plasma DNA and its relation to disease activity in systemic lupus erythematosus," American Journal of Medicine, vol. 77, no. 1, pp. 23-34, 1984.

[107] M. H. Jørgensen, O. P. Rekvig, R. S. Jacobsen, S. Jacobsen, and K. A. Fenton, "Circulating levels of chromatin fragments are inversely correlated with anti-dsDNA antibody levels in human and murine systemic lupus erythematosus," Immunology Letters, vol. 138, no. 2, pp. 179-186, 2011.

[108] J. Williams R.C., C. C. Malone, C. Meyers, P. Decker, and S. Muller, "Detection of nucleosome particles in serum and plasma from patients with systemic lupus erythematosus using monoclonal antibody 4H7," Journal of Rheumatology, vol. 28, no. 1, pp. 81-94, 2001.

[109] S. P. Keusseyan, N. P. Silva, M. O. Hilario, E. M. Okuda, M. T. Terreri, and L. E. Andrade, "Diagnostic performance and clinical associations of antibodies to the chromatin antigenic system in juvenile systemic lupus erythematosus," Revista Brasileira de Reumatologia, vol. 52, pp. 703-712, 2012.

[110] L. M. Campos, M. H. Kiss, M. A. Scheinberg, C. L. Mangueira, and C. A. Silva, "Antinucleosome antibodies in patients with juvenile systemic lupus erythematosus," Lupus, vol. 15, pp. 496$500,2006$.
[111] A. A. Jesus, L. M. Campos, B. L. Liphaus et al., "Anti-Clq, antichromatin/nucleosome, and anti-dsDNA antibodies in juvenile systemic lupus erythematosus patients," Revista Brasileira de Reumatologia, vol. 52, pp. 976-981, 2012.

[112] J.-F. Wu, Y.-H. Yang, L.-C. Wang, J.-H. Lee, E.-Y. Shen, and B.-L. Chiang, "Antinucleosome antibodies correlate with the disease severity in children with systemic lupus erythematosus," Journal of Autoimmunity, vol. 27, no. 2, pp. 119-124, 2006.

[113] L. Zhang, A. M. Bertucci, R. Ramsey-Goldman, E. R. HarshaStrong, R. K. Burt, and S. K. Datta, "Major pathogenic steps in human lupus can be effectively suppressed by nucleosomal histone peptide epitope-induced regulatory immunity," Clinical Immunology, vol. 149, pp. 365-378, 2013.

[114] E. W. Johns, "History, definitions, and problems," in The HMG Cromosomal Proteins, E. W. Johns, Ed., pp. 1-8, Academic Press, New York, NY, USA, 1982.

[115] J. S. Zlatanova, "Immunochemical approaches to the study of histone $\mathrm{H} 1$ and high mobility group chromatin proteins," Molecular and Cellular Biochemistry, vol. 92, no. 1, pp. 1-22, 1990.

[116] National Library of Medicine, "High Mobility Group Proteins," 2014, http://www.nlm.nih.gov/cgi/mesh/2011/MB_ cgi? mode $=$ \&term $=$ High + Mobility + Group + Proteins .

[117] S. Weisbrod and H. Weintraub, "Isolation of a subclass of nuclear proteins responsible for conferring a DNase I-sensitive structure on globin chromatin," Proceedings of the National Academy of Sciences of the United States of America, vol. 76, no. 2, pp. 630-634, 1979.

[118] P. J. Gonzalez and E. Palacian, "Structural and transcriptional properties of different nucleosomal particles containing high mobility group proteins 14 and 17 (HMG 14/17)," Journal of Biological Chemistry, vol. 265, no. 14, pp. 8225-8229, 1990.

[119] J. K. W. Mardian, A. E. Paton, G. J. Bunick, and D. E. Olins, "Nucleosome cores have two specific binding sites for nonhistone chromosomal proteins HMG 14 and HMG 17," Science, vol. 209, no. 4464, pp. 1534-1536, 1980.

[120] G. Sandeen, W. I. Wood, and G. Felsenfeld, "The interaction of high mobility proteins HMG14 and 17 with nucleosomes," Nucleic Acids Research, vol. 8, no. 17, pp. 3757-3778, 1980.

[121] M. Bustin, P. S. Becerra, M. P. Crippa, D. A. Lehn, J. M. Pash, and J. Shiloach, "Recombinant human chromosomal proteins HMG-14 and HMG-17," Nucleic Acids Research, vol. 19, no. 11, pp. 3115-3121, 1991.

[122] M. Bustin, J. Reisch, L. Einck, and J. H. Klippel, "Autoantibodies to nucleosomal proteins: antibodies to HMG-17 in autoimmune diseases," Science, vol. 215, no. 4537, pp. 1245-1247, 1982.

[123] A. Hayashi, H. Nagafuchi, I. Ito, K. Hirota, M. Yoshida, and S. Ozaki, "Lupus antibodies to the HMGB1 chromosomal protein: epitope mapping and association with disease activity," Modern Rheumatology, vol. 19, no. 3, pp. 283-292, 2009.

[124] V. Urbonaviciute, B. G. Fürnrohr, S. Meister et al., "Induction of inflammatory and immune responses by HMGB1-nucleosome complexes: implications for the pathogenesis of SLE," Journal of Experimental Medicine, vol. 205, no. 13, pp. 3007-3018, 2008.

[125] B. Wittemann, G. Neuer, H. Michels, H. Truckenbrodt, and F. A. Bautz, "Autoantibodies to nonhistone chromosomal proteins HMG-1 and HMG-2 in sera of patients with juvenile rheumatoid arthritis," Arthritis and Rheumatism, vol. 33, no. 9, pp. 13781383, 1990.

[126] G. Neuer, M. Bustin, H. Michels, H. Truckenbrodt, and F. A. Bautz, "Autoantibodies to the chromosomal protein HMG-17 in 
juvenile rheumatoid arthritis," Arthritis and Rheumatism, vol. 35, no. 4, pp. 472-475, 1992.

[127] R. W. Burlingame, R. L. Rubin, and A. M. Rosenberg, "Autoantibodies to chromatin components in juvenile rheumatoid arthritis," Arthritis and Rheumatism, vol. 36, no. 6, pp. 836-841, 1993.

[128] A. M. Rosenberg and D. M. Cordeiro, "Relationship between sex and antibodies to high mobility group proteins 1 and 2 in juvenile idiopathic arthritis," Journal of Rheumatology, vol. 27, no. 10, pp. 2489-2493, 2000.

[129] J. C. Monier, J. Ritter, C. Caux et al., "Canine systemic lupus erythematosus. II: antinuclear antibodies," Lupus, vol. 1, no. 5, pp. 287-293, 1992.

[130] L. M. Ayer, R. L. Rubin, G. H. Dixon, and M. J. Fritzler, "Antibodies to HMG proteins in patients with drug-induced autoimmunity," Arthritis and Rheumatism, vol. 37, no. 1, pp. 98103, 1994.

[131] L. M. Ayer, J.-L. Senécal, L. Martin, G. H. Dixon, and M. J. Fritzler, "Antibodies to high mobility group proteins in systemic sclerosis," Journal of Rheumatology, vol. 21, no. 11, pp. 2071-2075, 1994.

[132] H. Uesugi, S. Ozaki, J. Sobajima et al., "Prevalence and characterization of novel pANCA, antibodies to the high mobility group non-histone chromosomal proteins HMG1 and HMG2, in systemic rheumatic diseases," Journal of Rheumatology, vol. 25, no. 4, pp. 703-709, 1998.

[133] J. H. Morse, R. J. Barst, M. Fotino, Y. Zhang, E. Flaster, and M. J. Fritzler, "Primary pulmonary hypertension: immunogenetic response to high-mobility group (HMG) proteins and histone," Clinical and Experimental Immunology, vol. 106, no. 2, pp. 389395, 1996.

[134] J. Sobajima, S. Ozaki, F. Osakada et al., "Novel autoantigens of perinuclear anti-neutrophil cytoplasmic antibodies (P-ANCA) in ulcerative colitis: non-histone chromosomal proteins, HMG1 and HMG2," Clinical and Experimental Immunology, vol. 107, no. 1, pp. 135-140, 1997.

[135] J. Sobajima, S. Ozaki, H. Uesugi et al., "Prevalence and characterization of perinuclear anti-neutrophil cytoplasmic antibodies (P-ANCA) directed against HMG1 and HMG2 in ulcerative colitis (UC)," Clinical and Experimental Immunology, vol. 111, no. 2, pp. 402-407, 1998.

[136] M. Bustin, B. Dunn, R. Gillette, E. Mendelsohn, and N. Soares, "Antigenic determinants of high mobility group chromosomal proteins 1 and 2," Biochemistry, vol. 21, no. 26, pp. 6773-6777, 1982.

[137] S. Fida, M. A. Myers, S. Whittingham, M. J. Rowley, S. Ozaki, and I. R. Mackay, "Autoantibodies to the transcriptional factor SOX13 in primary biliary cirrhosis compared with other diseases," Journal of Autoimmunity, vol. 19, no. 4, pp. 251-257, 2002.

[138] H. Kasimiotis, M. A. Myers, A. Argentaro et al., "Sex-determining region Y-related protein SOX13 is a diabetes autoantigen expressed in pancreatic islets," Diabetes, vol. 49, no. 4, pp. 555$561,2000$.

[139] R. Manthorpe, H. Permin, and U. Tage-Jensen, "Auto-antibodies in Sjogren's syndrome. With special reference to liver-cell membrane antibody (LMA)," Scandinavian Journal of Rheumatology, vol. 8, no. 3, pp. 168-172, 1979.

[140] S. Barnay-Verdier, L. Fattoum, C. Borde, S. Kaveri, S. Gibot, and V. Maréchal, "Emergence of autoantibodies to HMGB1 is associated with survival in patients with septic shock," Intensive Care Medicine, vol. 37, no. 6, pp. 957-962, 2011.
[141] T. Nakano, C.-Y. Lai, S. Goto et al., "Role of antinuclear antibodies in experimental and clinical liver transplantation," Transplantation Proceedings, vol. 38, no. 10, pp. 3605-3606, 2006.

[142] T. Nakano, S. Goto, C.-Y. Lai et al., "Experimental and clinical significance of antinuclear antibodies in liver transplantation," Transplantation, vol. 83, no. 8, pp. 1122-1125, 2007.

[143] M. E. Bianchi, L. Falciola, S. Ferrari, and D. M. J. Lilley, "The DNA binding site of HMG1 protein is composed of two similar segments (HMG boxes), both of which have counterparts in other eukaryotic regulatory proteins," The EMBO Journal, vol. 11, no. 3, pp. 1055-1063, 1992.

[144] M. E. Bianchi and A. Manfredi, "Chromatin and cell death," Biochimica et Biophysica Acta-Gene Structure and Expression, vol. 1677, no. 1-3, pp. 181-186, 2004.

[145] H. Wang, O. Bloom, M. Zhang et al., "HMG-1 as a late mediator of endotoxin lethality in mice," Science, vol. 285, no. 5425, pp. 248-251, 1999.

[146] P. Scaffidi, T. Misteli, and M. E. Bianchi, "Release of chromatin protein HMGB1 by necrotic cells triggers inflammation," Nature, vol. 418, pp. 191-195, 2002.

[147] P. Rovere-Querini, A. Capobianco, P. Scaffidi et al., "HMGB1 is an endogenous immune adjuvant released by necrotic cells," EMBO Reports, vol. 5, no. 8, pp. 825-830, 2004.

[148] M. T. Lotze and K. J. Tracey, "High-mobility group box 1 protein (HMGB1): nuclear weapon in the immune arsenal," Nature Reviews Immunology, vol. 5, no. 4, pp. 331-342, 2005.

[149] T. Nakano, C. L. Chen, and S. Goto, "Nuclear antigens and auto/alloantibody responses: friend or foe in transplant immunology," Clinical and Developmental Immunology, vol. 2013, Article ID 267156, 9 pages, 2013.

[150] E. Abraham, J. Arcaroli, A. Carmody, H. Wang, and K. J. Tracey, "Cutting edge: HMG-1 as a mediator of acute lung inflammation," Journal of Immunology, vol. 165, no. 6, pp. 29502954, 2000.

[151] B. Degryse, T. Bonaldi, P. Scaffidi et al., "The high mobility group (HMG) boxes of the nuclear protein HMG1 induce chemotaxis and cytoskeleton reorganization in rat smooth muscle cells," Journal of Cell Biology, vol. 152, no. 6, pp. 11971206, 2001.

[152] A. Tsung, R. Sahai, H. Tanaka et al., "The nuclear factor HMGB1 mediates hepatic injury after murine liver ischemiareperfusion," Journal of Experimental Medicine, vol. 201, no. 7, pp. 1135-1143, 2005.

[153] H. Sawa, T. Ueda, Y. Takeyama et al., "Blockade of high mobility group box-1 protein attenuates experimental severe acute pancreatitis," World Journal of Gastroenterology, vol. 12, no. 47, pp. 7666-7670, 2006.

[154] R. S. Goldstein, A. Bruchfeld, L. Yang et al., "Cholinergic antiinflammatory pathway activity and High Mobility Group Box-1 (HMGB1) serum levels in patients with rheumatoid arthritis," Molecular Medicine, vol. 13, no. 3-4, pp. 210-215, 2007.

[155] N. Hamada, T. Maeyama, T. Kawaguchi et al., "The role of high mobility group boxl in pulmonary fibrosis," American Journal of Respiratory Cell and Molecular Biology, vol. 39, no. 4, pp. 440447, 2008.

[156] S. Muhammad, W. Barakat, S. Stoyanov et al., "The HMGB1 receptor RAGE mediates ischemic brain damage," Journal of Neuroscience, vol. 28, no. 46, pp. 12023-12031, 2008.

[157] T. Hoshina, K. Kusuhara, K. Ikeda, Y. Mizuno, M. Saito, and T. Hara, "High mobility group box 1 (HMGB1) and macrophage 
migration inhibitory factor (MIF) in Kawasaki disease," Scandinavian Journal of Rheumatology, vol. 37, no. 6, pp. 445-449, 2008.

[158] D. J. Kaczorowski, A. Nakao, R. Vallabhaneni et al., "Mechanisms of toll-like receptor 4 (TLR4)-mediated inflammation after cold ischemia/reperfusion in the heart," Transplantation, vol. 87, no. 10, pp. 1455-1463, 2009.

[159] Y. Albayrak, A. Albayrak, M. Celik et al., "High mobility group box protein-1 (HMGB-1) as a new diagnostic marker in patients with acute appendicitis," Scandinavian Journal of Trauma, Resuscitation and Emergency Medicine, vol. 19, article 27, 2011.

[160] T. Kohno, T. Anzai, H. Shimizu et al., "Impact of serum high-mobility group box 1 protein elevation on oxygenation impairment after thoracic aortic aneurysm repair," Heart and Vessels, vol. 26, no. 3, pp. 306-312, 2011.

[161] R. Takahata, S. Ono, H. Tsujimoto et al., "Postoperative serum concentrations of high mobility group box chromosomal protein-1 correlates to the duration of SIRS and pulmonary dysfunction following gastrointestinal surgery," Journal of Surgical Research, vol. 170, no. 1, pp. e135-e140, 2011.

[162] J. Choi, H. J. Min, and J.-S. Shin, "Increased levels of HMGB1 and pro-inflammatory cytokines in children with febrile seizures," Journal of Neuroinflammation, vol. 8, article 135, 2011.

[163] R. Haraba, V. I. Suica, E. Uyy, L. Ivan, and F. Antohe, "Hyperlipidemia stimulates the extracellular release of the nuclear high mobility group box 1 protein," Cell and Tissue Research, vol. 346, no. 3, pp. 361-368, 2011.

[164] K. Naruse, T. Sado, T. Noguchi et al., "Peripheral RAGE (Receptor for Advanced Glycation Endproducts)-ligands in normal pregnancy and preeclampsia: novel markers of inflammatory response," Journal of Reproductive Immunology, vol. 93, no. 2, pp. 69-74, 2012.

[165] A. Albayrak, M. H. Uyanik, S. Cerrah et al., "Is HMGB1 a new indirect marker for revealing fibrosis in chronic hepatitis and a new therapeutic target in treatment?" Viral Immunology, vol. 23, no. 6, pp. 633-638, 2010.

[166] R. R. Zhou, H. B. Liu, J. P. Peng et al., "High mobility group box chromosomal protein 1 in acute-on-chronic liver failure patients and mice with ConA-induced acute liver injury," Experimental and Molecular Pathology, vol. 93, pp. 213-219, 2012.

[167] R.-R. Zhou, S.-S. Zhao, M.-X. Zou et al., "HMGB1 cytoplasmic translocation in patients with acute liver failure," BMC Gastroenterology, vol. 11, article 21, 2011.

[168] R. E. Voll, V. Urbonaviciute, B. Fürnrohr, M. Herrmann, and J. R. Kalden, "The role of high-mobility group box 1 protein in the pathogenesis of autoimmune diseases," Current Rheumatology Reports, vol. 10, no. 5, pp. 341-342, 2008.

[169] D. S. Pisetsky, H. Erlandsson-Harris, and U. Andersson, "Highmobility group box protein 1 (HMGB1): an alarmin mediating the pathogenesis of rheumatic disease," Arthritis Research and Therapy, vol. 10, no. 3, article 209, 2008.

[170] Z. Wen, L. Xu, X. Chen et al., "Autoantibody induction by DNA-containing immune complexes requires HMGB1 with the TLR2/microRNA-155 pathway," The Journal of Immunology, vol. 190, pp. 5411-5422, 2013.

[171] D. A. Abdulahad, J. Westra, J. Bijzet et al., "Urine levels of HMGB1 in systemic lupus erythematosus patients with and without renal manifestations," Arthritis Research\& Therapy, vol. 14, p. R184, 2012.
[172] P. Santoro, M. de Andrea, G. Migliaretti, C. Trapani, S. Landolfo, and M. Gariglio, "High prevalence of autoantibodies against the nuclear high mobility group (HMG) protein SSRP1 in sera from patients with systemic lupus erythematosus, but not other rheumatic diseases," Journal of Rheumatology, vol. 29, no. 1, pp. 90-93, 2002.

[173] J. Li, H. Xie, T. Wen, H. Liu, W. Zhu, and X. Chen, "Expression of high mobility group box chromosomal protein 1 and its modulating effects on downstream cytokines in systemic lupus erythematosus," Journal of Rheumatology, vol. 37, no. 4, pp. 766$775,2010$.

[174] J. Cardinal, P. Pan, R. Dhupar et al., "Cisplatin prevents high mobility group box 1 release and is protective in a murine model of hepatic ischemia/reperfusion injury," Hepatology, vol. 50, no. 2, pp. 565-574, 2009.

[175] T. Kohno, T. Anzai, H. Kaneko et al., "High-mobility group box 1 protein blockade suppresses development of abdominal aortic aneurysm," Journal of Cardiology, vol. 59, no. 3, pp. 299-306, 2012.

[176] V. Urbonaviciute and R. E. Voll, "High-mobility group box 1 represents a potential marker of disease activity and novel therapeutic target in systemic lupus erythematosus," Journal of Internal Medicine, vol. 270, no. 4, pp. 309-318, 2011.

[177] C. Ye, J. G. Choi, S. Abraham et al., "Human macrophage and dendritic cell-specific silencing of high-mobility group protein B1 ameliorates sepsis in a humanized mouse model," Proceedings of the National Academy of Sciences of the United States of America, vol. 109, pp. 21052-21057, 2012.

[178] R. Haraba, E. Uyy, V. I. Suica, L. Ivan, and F. Antohe, "Fluvastatin reduces the high mobility group box 1 protein expression in hyperlipidemia," International Journal of Cardiology, vol. 150, no. 1, pp. 105-107, 2011.

[179] V. Brinkmann, U. Reichard, C. Goosmann et al., "Neutrophil extracellular traps kill bacteria," Science, vol. 303, no. 5663, pp. 1532-1535, 2004.

[180] V. Brinkmann and A. Zychlinsky, "Neutrophil extracellular traps: is immunity the second function of chromatin?" The Journal of Cell Biology, vol. 198, pp. 773-783, 2012.

[181] B. G. Yipp and P. Kubes, "NETosis: how vital is it?" Blood, vol. 122, pp. 2784-2794, 2013.

[182] K. Pittman and P. Kubes, "Damage-associated molecular patterns control neutrophil recruitment," Journal of Innate Immunity, vol. 5, pp. 315-323, 2013.

[183] V. Papayannopoulos, K. D. Metzler, A. Hakkim, and A. Zychlinsky, "Neutrophil elastase and myeloperoxidase regulate the formation of neutrophil extracellular traps," Journal of Cell Biology, vol. 191, no. 3, pp. 677-691, 2010.

[184] A. Hakkim, B. G. Fürnrohr, K. Amann et al., "Impairment of neutrophil extracellular trap degradation is associated with lupus nephritis," Proceedings of the National Academy of Sciences of the United States of America, vol. 107, no. 21, pp. 9813-9818, 2010.

[185] T. A. Fuchs, U. Abed, C. Goosmann et al., "Novel cell death program leads to neutrophil extracellular traps," Journal of Cell Biology, vol. 176, no. 2, pp. 231-241, 2007.

[186] B. McDonald, R. Urrutia, B. G. Yipp, C. N. Jenne, and P. Kubes, "Intravascular neutrophil extracellular traps capture bacteria from the bloodstream during sepsis," Cell Host \& Microbe, vol. 12, pp. 324-333, 2012.

[187] D. Simon, H. U. Simon, and S. Yousefi, "Extracellular DNA traps in allergic, infectious, and autoimmune diseases," Allergy, vol. 68, pp. 409-416, 2013. 
[188] T. Dörner, "SLE in 2011: deciphering the role of NETs and networks in SLE," Nature Reviews Rheumatology, vol. 8, no. 2, pp. 68-70, 2012.

[189] J. E. Craft, "Dissecting the immune cell mayhem that drives lupus pathogenesis," Science Translational Medicine, vol. 3, no. 73, Article ID 73ps9, 2011.

[190] R. Lande, D. Ganguly, V. Facchinetti et al., "Neutrophils activate plasmacytoid dendritic cells by releasing self-DNApeptide complexes in systemic lupus erythematosus," Science Translational Medicine, vol. 3, no. 73, Article ID 73ra19, 2011.

[191] G. S. Garcia-Romo, S. Caielli, B. Vega et al., "Netting neutrophils are major inducers of type I IFN production in pediatric systemic lupus erythematosus," Science Translational Medicine, vol. 3, no. 73, Article ID 73ra20, 2011.

[192] E. Villanueva, S. Yalavarthi, C. C. Berthier et al., "Netting neutrophils induce endothelial damage, infiltrate tissues, and expose immunostimulatory molecules in systemic lupus erythematosus," Journal of Immunology, vol. 187, no. 1, pp. 538-552, 2011.

[193] J. Leffler, M. Martin, B. Gullstrand et al., "Neutrophil extracellular traps that are not degraded in systemic lupus erythematosus activate complement exacerbating the disease," Journal of Immunology, vol. 188, no. 7, pp. 3522-3531, 2012.

[194] C. N. Jenne and P. Kubes, "NETs tangle with HIV," Cell Host \& Microbe, vol. 12, pp. 5-7, 2012.

[195] C. N. Jenne, C. H. Wong, F. J. Zemp et al., "Neutrophils recruited to sites of infection protect from virus challenge by releasing neutrophil extracellular traps," Cell Host \& Microbe, vol. 13, pp. 169-180, 2013.

[196] K. Kessenbrock, M. Krumbholz, U. Schönermarck et al., "Netting neutrophils in autoimmune small-vessel vasculitis," Nature Medicine, vol. 15, no. 6, pp. 623-625, 2009.

[197] M. Phillipson and P. Kubes, "The neutrophil in vascular inflammation," Nature Medicine, vol. 17, no. 11, pp. 1381-1390, 2011.

[198] P. Kubes and W. Z. Mehal, "Sterile inflammation in the liver," Gastroenterology, vol. 143, pp. 1158-1172, 2012. 


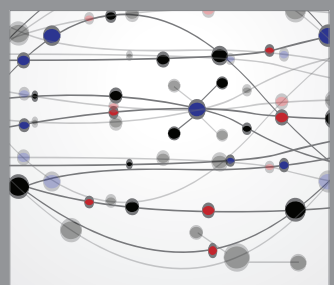

The Scientific World Journal
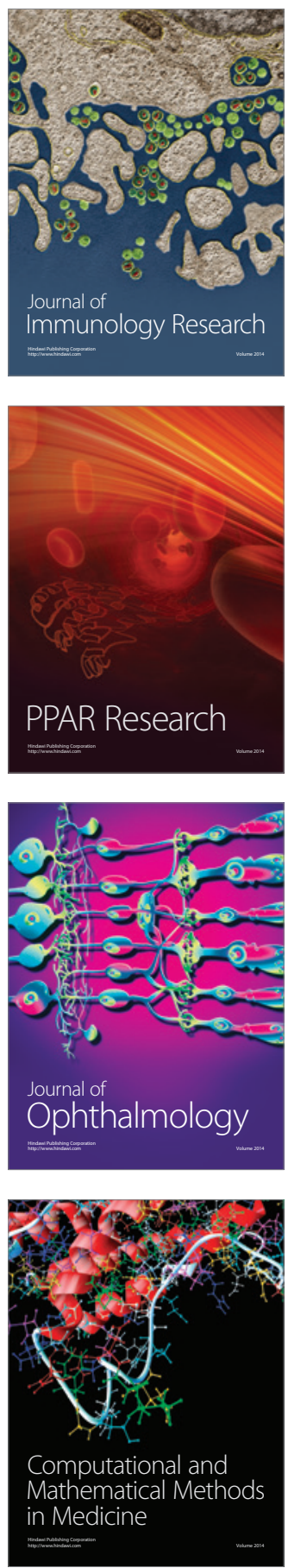

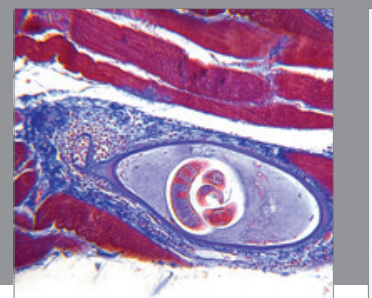

Gastroenterology

Research and Practice
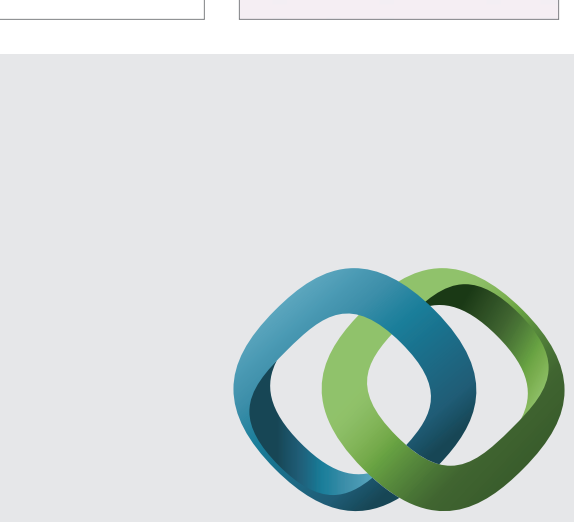

\section{Hindawi}

Submit your manuscripts at

http://www.hindawi.com
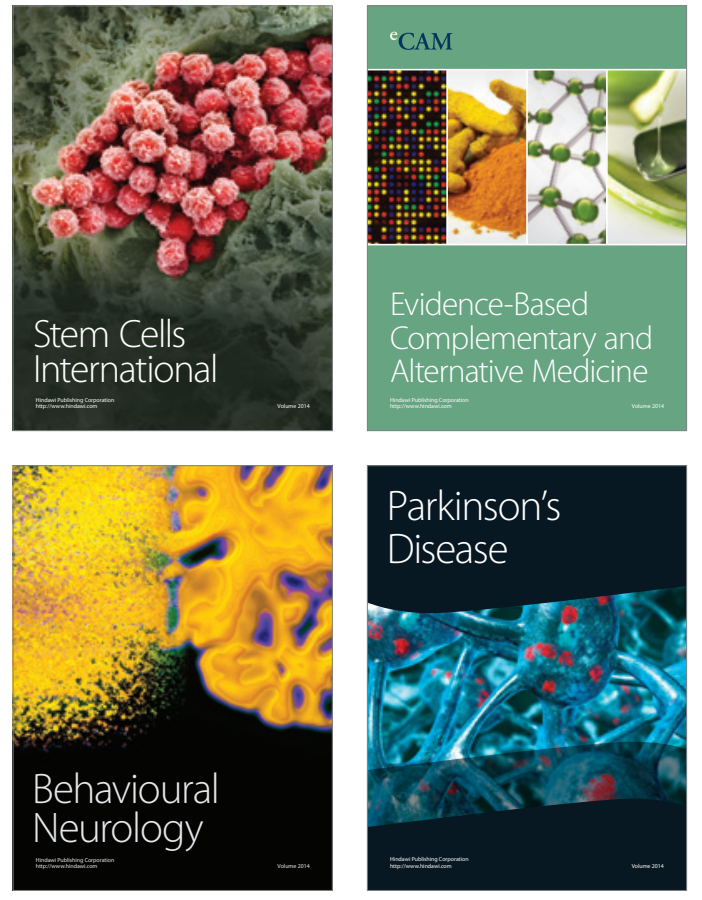
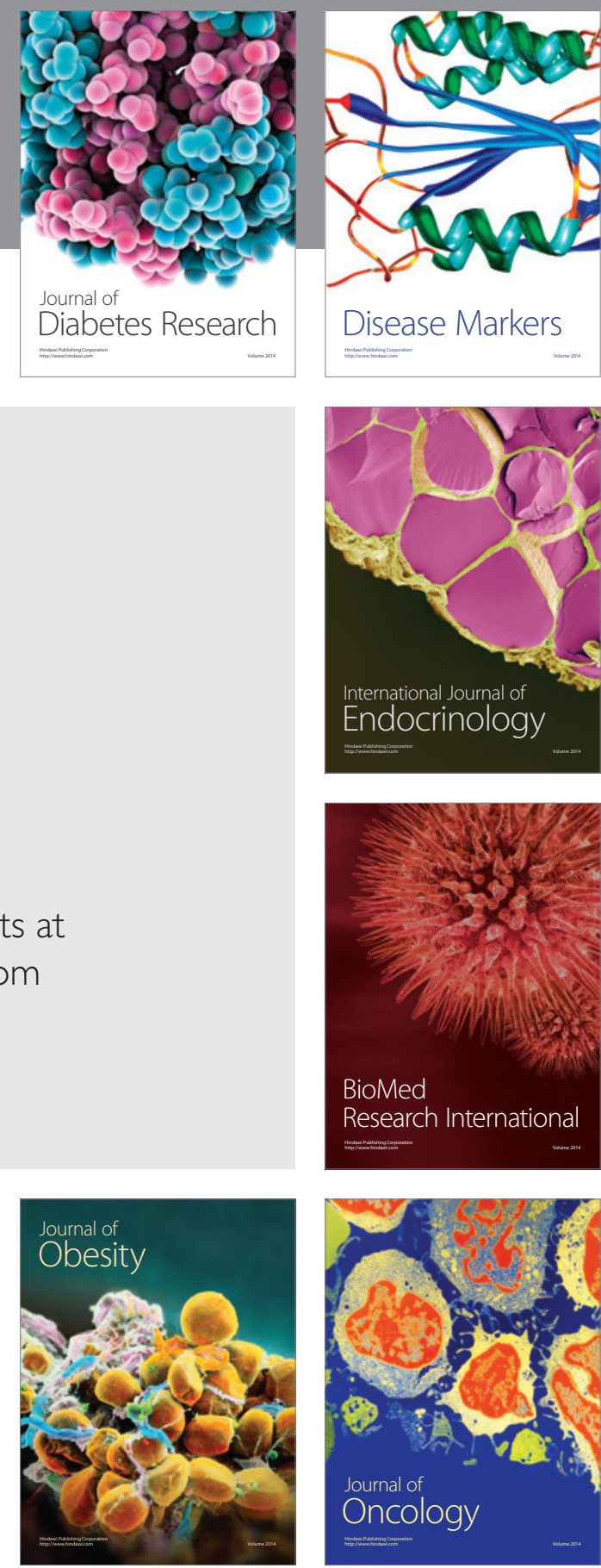

Disease Markers
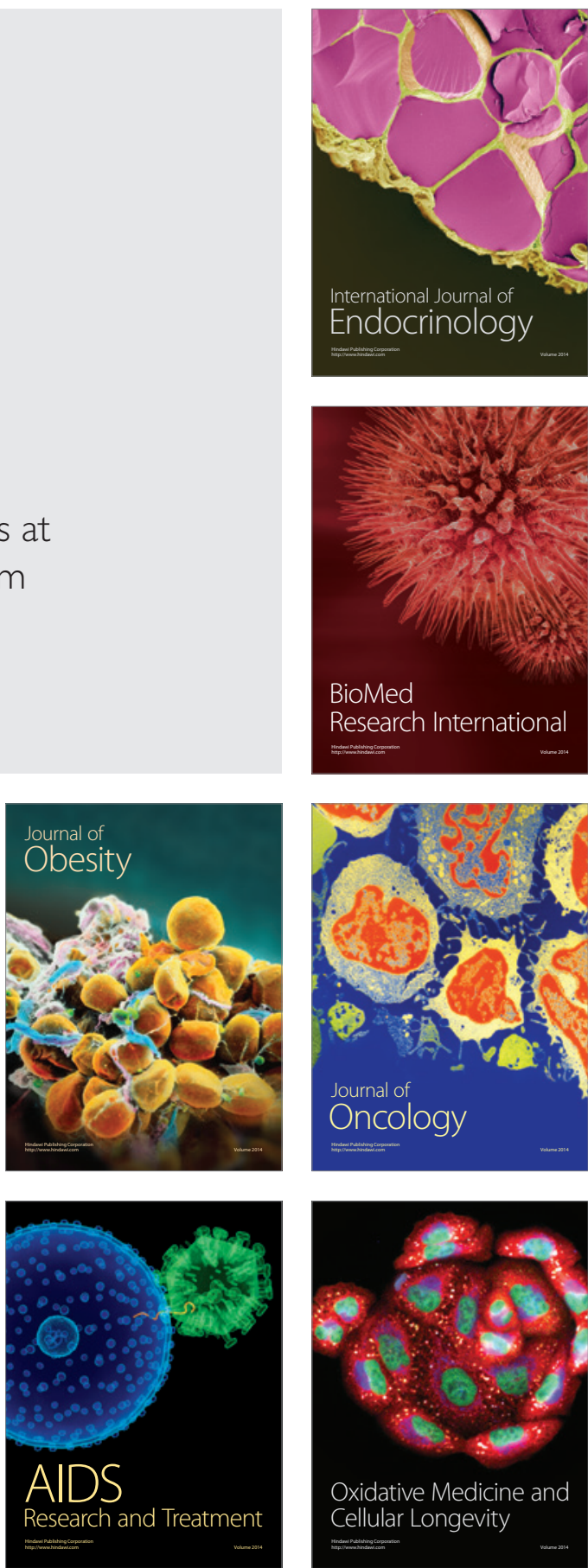